\title{
Atomic Spectroscopy . \\ Review: Application of LIBS to Elemental Analysis and Mapping of Plant Samples
}

\author{
Vivek K. Singh, ${ }^{\mathrm{a}, *}$ Neha Sharma, ${ }^{\mathrm{a}}$ Onkar N. Verma, ${ }^{\mathrm{a}}$ Virendra K. Singh, ${ }^{\mathrm{b}}$ Durgesh K. Tripathi, \\ Yonghoon Lee, ${ }^{\mathrm{d}}$ Sandeep Kumar, ${ }^{\mathrm{d}}$ Piyush K. Rai, ${ }^{\mathrm{e}}$ and M.A. Gondal ${ }^{\mathrm{f}}$ \\ a School of Physics, Shri Mata Vaishno Devi University, Katra 182320, Jammu and Kashmir, India \\ b Department of Plant Pathology, College of Agriculture, Banda University of Agriculture and Technology, Banda, UP 210001, India \\ c Amity Institute of Organic Agriculture (AIOA), Amity University, Noida, Uttar Pradesh 201313 \\ d Department of Chemistry, Mokpo National University, Jeonnam 58554, Republic of Korea \\ e Department of Botany, Patna Women's College, Patna 800001, Bihar, India \\ f Laser Research Group, Department of Physics, King Fahd University of Petroleum and Minerals, Dhahran 31261, Saudi Arabia
}

Received: November 27, 2020; Revised: December 14, 2020; Accepted: December 14, 2020; Available online: December 26, 2020.

DOI: $10.46770 / A S .2020 .201$

ABSTRACT: Trace minerals and metallic elements play a key role in plant metabolism and function. Therefore, it is important to understand the movement and distribution of trace minerals within various parts of plants in order to understand their metabolic pathways. Information on the localization of minerals can be utilized in the fields of plant science, agriculture, and food technologies. In this context, herein, we review the feasibility of application of laser-induced breakdown spectroscopy (LIBS) as a technique for trace element detection and mapping in different plant matrices. LIBS is a well-established technique that can be used to perform rapid multi-elemental detection in various types of samples, including plants. Owing to the unique capabilities of LIBS, its field applications are growing rapidly, particularly in the area of plant science. Here, our primary emphasis is on the quantitative and qualitative elemental imaging of different varieties of plant species that are of importance as medicines and foodstuffs. In this review article, we present an exhaustive survey of recent developments, including technical advances and recent work involving the detection of nanoparticles in plant samples and in the monitoring of soil content. The future potential of LIBS and the viability of its possible applications to the detection of essential minerals and heavy metals in plants used as foods or of medicinal importance are also discussed.

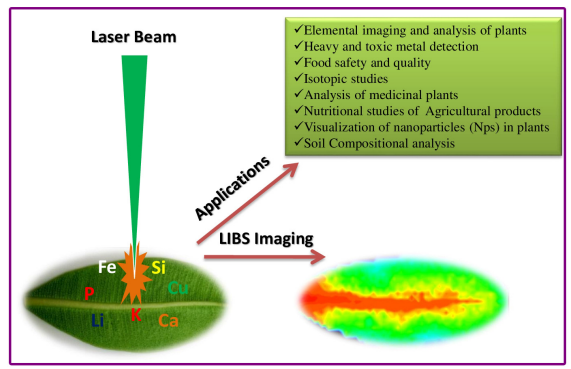

\section{INTRODUCTION}

Currently, in agricultural science, the major issues affecting global crop production include nutrient management, contamination by heavy and toxic metals, and optimum plant productivity. Plants can grow for several decades, and they are composed of all elements in different proportions. The elements found in plants are considered to be either ( $i$ ) macronutrients, such as $\mathrm{Ca}, \mathrm{K}, \mathrm{Mg}, \mathrm{N}$, $\mathrm{P}$, and $\mathrm{S}$, or (ii) micronutrients such as $\mathrm{B}, \mathrm{Cu}, \mathrm{Cl}, \mathrm{Fe}, \mathrm{Mn}, \mathrm{Mo}, \mathrm{Na}$, and $\mathrm{Zn}$. These elements are very important for plant development and growth. ${ }^{1}$ It is generally accepted that the proper intake of these elements is correlated with a reduced risk factor for various diseases. Thus, measuring the content of these elements in different parts of plants is crucial for the detailed understanding of the nutritional value of crops. This is of particular importance to produce food stuffs such as cereals, vegetables, and fruits. ${ }^{2}$ In contrast, some heavy and toxic metallic elements, including As, $\mathrm{Cr}$, $\mathrm{Cd}, \mathrm{Li}, \mathrm{Pb}$, and $\mathrm{Hg}$ exhibit toxic effects even in trace amounts. These heavy metal elements enter plants through various external agents, such as pesticides, industrial waste, solid waste, and fertilizers, as well as from soil and water from contaminated areas, and damaged crops. Inside the plants, these heavy metals bind to $\mathrm{S}$ and $\mathrm{N}$ and functional groups of biological molecules containing oxygen such as enzymes, proteins, nucleic acids, and carbohydrates, and interfere with their normal function. ${ }^{3}$ In 
addition, the processes of industrialization and urbanization, human activities and excessive use of fertilizers have adversely impacted various plant species. Thus, various types of diseases, caused by fungi, bacteria, nematodes, environmental conditions, and deficiencies of minerals, have been relatively recently observed in plants.

Therefore, performing elemental imaging to obtain the spatial distributions of elements in different parts of the plant at the early stage of growth is very important as it allows the diagnosis of problems associated with abnormalities in these distributions. This is also vital when deciding the necessary remedial measures. It is also crucial to investigate the appropriate distributions of essential elements, along with the distributions of the heavy and toxic elements (heavy or soft) in different parts of plants, to limit the damage caused by them. Several studies have focused on the detection of elements and determination of their quantitative distributions, to understand the localization and transportation of heavy and trace elements within different plant tissues and cells, ${ }^{1}$ using various advanced analytical spectroscopic techniques. Spectroscopic techniques have been shown to be a robust tool with the appropriate spatial resolution in a broad variety of research areas within plant science. ${ }^{4,5}$ They enable the simultaneous observation of mineral elements and their mapping within the material of interest. These diagnostic techniques have made a significant contribution to forensic ${ }^{6}$ and bio-medical ${ }^{7}$ applications of plant science. Numerous techniques, in particular, laser-induced breakdown spectroscopy (LIBS), X-ray fluorescence (XRF), tunneling electron microscopy-energy dispersive X-ray spectroscopy (TEM-EDS), and scanning electron microscopyenergy dispersive X-ray spectroscopy (SEM-EDS) ${ }^{1}$ can directly generate elemental images and distributions of plant tissues. More precisely, microscopic investigations of biological specimens using X-ray-based imaging tools have garnered significant interest in plant science. ${ }^{8,9,10}$

LIBS is an atomic-emission-based diagnostic technique that is now being applied in plant science for imaging purposes. ${ }^{11}$ This technique boasts numerous advantages, including the fact that it obviates the need for sample preparation, allowing in-situ and in vivo detection. It also has excellent stand-off detection and multielemental analysis capabilities, is conceptually and experimentally simple, and has good potential for microanalysis when integrated with a microscope. Moreover, it can be used to analyze all forms of samples: solids, liquids, and gases. ${ }^{11}$ Hence, LIBS is considered to be well-suited to meet the various demands of real-time measurements in agricultural and plant sciences. Recently, LIBS and laser-ablation inductively coupled plasma mass spectrometry (LA-ICP-MS) have been successfully applied to the spatial characterization of bio-samples. ${ }^{12,13,14}$ The relative simplicity of the combination of LIBS and ICP-MS, the feasibility of singleshot multi-elemental inspection, and the potential to excite many sample types ${ }^{15}$ are the primary advantages of these techniques.
Heavy element detection in different parts of plants, without laborious sample preparation, ${ }^{16,17,18}$ is very important for phytoremediation. ${ }^{19}$ Phytoremediation techniques are a sustainable alternative approach to combat environmental contamination by heavy and toxic elements using plants. Typically, in such an approach, plant species are used to contain or drain heavy and toxic elements as well as radioactive isotopes. Most plant species are capable of absorbing and reducing the content of a diverse range of organic compounds in soil. ${ }^{20,21}$ There are many encouraging reasons that justify further research and development of phytoremediation technology. One specific advantage of phytoremediation is that it uses organisms in a natural manner and maintains the ecological balance of the environment, making it less damaging than conventional alternatives. . $2,23,24^{2}$

Therefore, in plant and agricultural sciences, basic investigations based on elemental imaging and quantification are essential for diagnosing the problems that arise because of the intake of various toxic heavy metals. ${ }^{25}$ These methods are also important in the context of food and nutritional research, to ensure global food productivity. Hence, this article principally focuses on the LIBS technique and its utility for the elemental detection and quantitative imaging of plants, including plants of medical importance. The use and application of LIBS in the monitoring of heavy and toxic metals in soil, plants, agricultural products, and food products are discussed in this review paper.

\section{LIBS INSTRUMENTATION FOR ELEMENTAL IMAGING}

LIBS is a robust technique for investigating the elemental and chemical constituents of samples without any sample preparation. Its relative simplicity and capability for performing rapid multielemental analyses on various types of materials makes it ideal to investigate a wide range of plant materials. ${ }^{26} \mathrm{~A}$ schematic of a typical LIBS experiment for the elemental imaging of plant samples was reported by Singh et al. In a LIBS experiment, a veryhigh-power pulsed laser is typically utilized to generate a laserinduced plasma at the sample surface. ${ }^{27}$ When the highly intense laser light is incident on the sample surface, the elements within the sample are first vaporized and then excited in a spark that subsequently turns into a hot plasma. The light emitted from the plasma upon cooling is detected and analyzed to measure the chemical constituents of the sample. The primary concern in the design of LIBS setups is the choice of the type of laser. Lasers with different pulse widths, pulse durations, and wavelengths have critically different effects on the generated microplasma. ${ }^{28}$ Pulsed lasers are usually preferred because of their stability, focusing action, high-energy output, and ease of application. ${ }^{28}$ LIBS has been used for a myriad of applications such as the detection of lighter elements including $\mathrm{C}, \mathrm{H}, \mathrm{N}, \mathrm{O}, \mathrm{Li}$, and $\mathrm{Be}$, elemental surface mapping, and depth profiling. In addition, it has been used 
to successfully address a broad variety of scientific challenges. ${ }^{29}$ LIBS has been used to monitor industrial processes and the characterization of jewelry products. It is also applied in soil, plant, and environmental studies, as well as in the investigation of mineral ores, the diversity of Martian geochemistry, and NPs. ${ }^{30}$ Liu et al. reviewed the fundamental aspects of LIBS and its applications in various fields, with a particular emphasis on the biomedical field. Their review includes environmental bio-aerosol detection and trace element detection in human samples using LIBS. ${ }^{31}$

Plant matrices are very complex and differ significantly for different varieties of plant species. Thus, a calibration-free LIBS (CF-LIBS) analysis approach for analyzing plants is very useful in quantifying the various elements present in plant samples, thus minimizing the matrix effect in complex biological samples. ${ }^{32}$ The CF-LIBS method is very useful for the analysis of materials of unknown composition, even when a matrix-matched standard is not available. Owing to these characteristics, this approach is very promising and well-suited for agricultural studies, which are often hindered by a lack of matrix-matched standards along with the complications introduced by significant matrix effects in agricultural products. ${ }^{28}$ Tongnoni et al. presented a critical review on the use of CF-LIBS, an advanced method used for multielemental analysis based on LIBS data. ${ }^{33}$ They noted that the CFLIBS technique relies on the measurement of line intensities, plasma electron densities, plasma temperatures, and Boltzmann distributions for the population of excited levels. In addition, an extensive summary was provided of all the quantitative results obtained via the CF-LIBS method that had been reported by the date of publication.

In general, there is a positive correlation between the intensities of spectral lines and element concentrations. Usually, changes in the concentration of an element in the plant can be obtained from spectral line intensities, and there is no need for further quantitative analysis. Sometimes, however, the relative content of an element is also required for the purposes of analysis, and this can be provided by CF-LIBS, with the advantage being that there is no need for standard samples. ${ }^{15}$ There are some other calibration methods that are commonly used for the quantitative LIBS analysis of samples, including plants. These include the principal component regression analysis method based on principal component analysis (PCA), partial least squares regression data analysis method, and artificial neural networks. ${ }^{15}$ These methods offer improved precision with respect to calibration curve methods.

In-situ single-pulse LIBS (SP-LIBS) is used to analyze plant samples via the acquisition of a single-shot LIBS spectrum. ${ }^{34,35}$ Recently, NP-enhanced LIBS (NPLIBS) has been adopted as a means to improve the analytical sensitivity of LIBS. ${ }^{36}$ Using this method, limits of detection (LoDs) can be enhanced. Modern instrumentation and methodology have been demonstrated to achieve high-resolution elemental mapping of the surfaces of samples and acquire elemental imaging distributions. ${ }^{37,38}$ By using state-of-the-art LIBS instrumentation, three-dimensional (3D) elemental mapping of biological samples is also possible. Such results indicate the potential of this approach for analyzing animal tissues. ${ }^{36}$ The LIBS technique can also be coupled with other techniques to provide better sensitivity and the best spatial resolution, compared with other existing analytical techniques.

Recently, the combination of LIBS with laser-induced fluorescence (LIF) has become a research topic of great interest, and LIBS-LIF is currently being used to analyze various types of materials, including plant samples, alloys, and soil samples, and for heavy-metal analysis in aqueous solutions. ${ }^{39}$ LIBS-LIF was first proposed by Kwong, and their team showed that this technology could help avoid matrix effects in elemental analysis. ${ }^{40}$ Recently, Jiang et al. applied LIBS-LIF as a rapid and sensitive analytical technique for trace $\mathrm{Pb}$ detection in several samples of Rheum officinale, which is a medicinal herb plant. ${ }^{39}$ In addition, Zhu et al. applied LIBS-LIF to the effective measurement of $\mathrm{Pb}$ in natural rhododendron leaf samples. ${ }^{41}$ The authors measured the $\mathrm{LoD}$ for $\mathrm{Pb}$ as $0.054 \mathrm{ppm}$. Very recently, Dhanada et al. published a review article that described the importance of the hyphenation of techniques such as LIBS, LIF, and Raman spectroscopy, as well as the applications of these combined methods. ${ }^{42}$ According to the reported literature, it is evident that in the future, LIBS in combination with other techniques (LIF and Raman) will prove to be an effective method for the multi-elemental imaging of plant tissue with greater sensitivity.

The 3D depth-profile imaging of plant tissues using ultrafast lasers, for example femtosecond lasers (fs-LIBS), is also a burgeoning field in plant science. Shuang et al used fs-LIBS to analyze the elemental content in poplar tree leaves and identified the elements N, P, K, Ca, Fe, Ti, Mn, and $\mathrm{Na}^{43}$ Specifically, in 2015, Carvalho et al. were the first to report the use of a fs-LIBS system in a systematic study to quantitatively determine the contents of macronutrients $\mathrm{Ca}, \mathrm{Mg}$, and $\mathrm{P}$ and micronutrients $\mathrm{Cu}$, $\mathrm{Fe}, \mathrm{Mn}$, and $\mathrm{Zn}$ of pelletized leaves from 31 different crop plants of economic value, which included a wide range of matrices. ${ }^{44}$ Recently, Kunz et al. used fs-LIBS for the elemental analysis of greenhouse-grown dallisgrass, wheat, soybean, and bell pepper plants under ambient environmental conditions. ${ }^{45}$ The results reported in the literature demonstrate that fs-LIBS can be utilized to analyze elemental content and realize imaging in plant tissues.

\section{APPLICATION OF LIBS TO ELEMENTAL IMAGING AND ANALYSIS}

The LIBS technique is very useful for analyzing plasma emission spectra because the intensity of the emitted plasma is proportional to the elements present in the sample. Recently, LIBS has garnered 


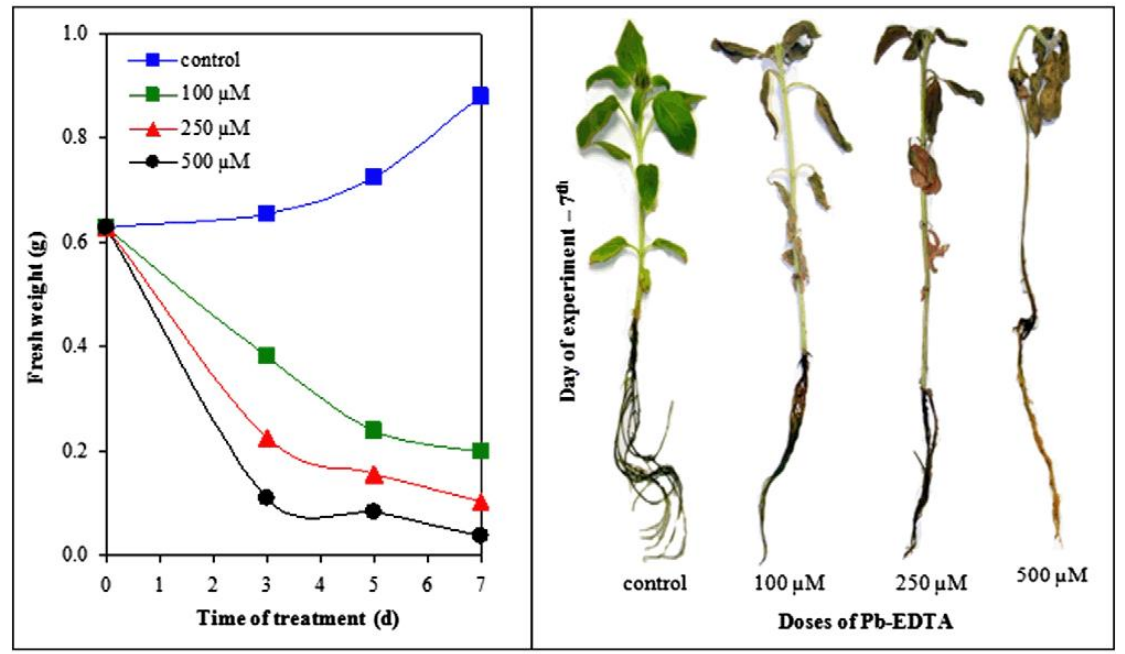

Fig. 1 Growth curves obtained from a LIBS and LA-ICP-MS analysis corresponding to different $\mathrm{Pb}$ doping concentrations (left) and photographs (right) of treated plants. Reproduced from Kaiser et al. ${ }^{49}$

tremendous interest in the field of biomedicine, owing to its applications in the detection of heavy and trace elements in various solid and liquid samples of plant materials. ${ }^{46}$ Here, we highlight the uses and applications of LIBS in the analysis of plant materials by the elemental imaging of trace minerals and heavy metals.

The LIBS analyses (both in bulk and spatially resolved modes) of some plants were reviewed and succinctly presented by Santos et al. ${ }^{47}$ Their review focused on the important role of metals in plant metabolism. The authors emphasized that the transportation and imaging/mapping of mineral elements within the different parts of plants is useful for understanding metabolic pathways. It was concluded that the information on the localization of specific ions within plants is of great interest in plant science and for the monitoring of environmental conditions. Samek et al. used fsLIBS for the spectrochemical detection of Fe within leaf samples, in order to investigate the spatial localization of the element. ${ }^{17}$ They found that LIBS can identify the accumulation of Fe ions in all parts of the plants. Kaiser et al. compared the spatial resolution of toxic elements $\mathrm{Cd}$ and $\mathrm{Pb}$ in the leaves and roots of botanical species; fs-LIBS was used for the investigation. ${ }^{48} \mathrm{Cd}$ and $\mathrm{Pb}$ in Helianthus annuus L. leaves were principally concentrated in veins and transported throughout the rest of the plant by xylem. Galiova et al. demonstrated the utility of LIBS to study the accumulation of $\mathrm{Pb}$ pollutant and also to image its distribution within the sample. ${ }^{18}$ The spatial distribution of $\mathrm{Pb}$ was imaged over a $5 \mathrm{~mm} \times 2 \mathrm{~mm}$ area, and the central vein was positioned in the middle of the region of interest. The authors were able to distinguish the central vein from the surrounding tissue in both samples based on the LIBS data. The LIBS results also indicated that the increased $\mathrm{Pb}$ concentration might have influenced the $\mathrm{K}$ and $\mathrm{Mn}$ concentrations and distributions in the plants.

Kaiser et al. utilized LIBS and LA-ICP-MS to map accumulated elements such as $\mathrm{Cu}, \mathrm{Mg}$, and $\mathrm{Pb}$ in sunflower leaves at resolutions of up to $200 \mu \mathrm{m} .{ }^{49}$ The authors performed their LIBS study on control and doped leaves to investigate the effect of $\mathrm{Pb}$ ions on the plants. Fig. 1 displays the growth curves of Helianthus annuus $L$. treated with different concentrations of $\mathrm{Pb}$ ions.

Considerable growth depression was observed in the plants, the magnitude of which depended on $\mathrm{Pb}$ treatment duration and concentration of $\mathrm{Pb}$ (II) ions, relative to the control plant samples. Moreover, after 7 days (at the final stage of the experiment), highly
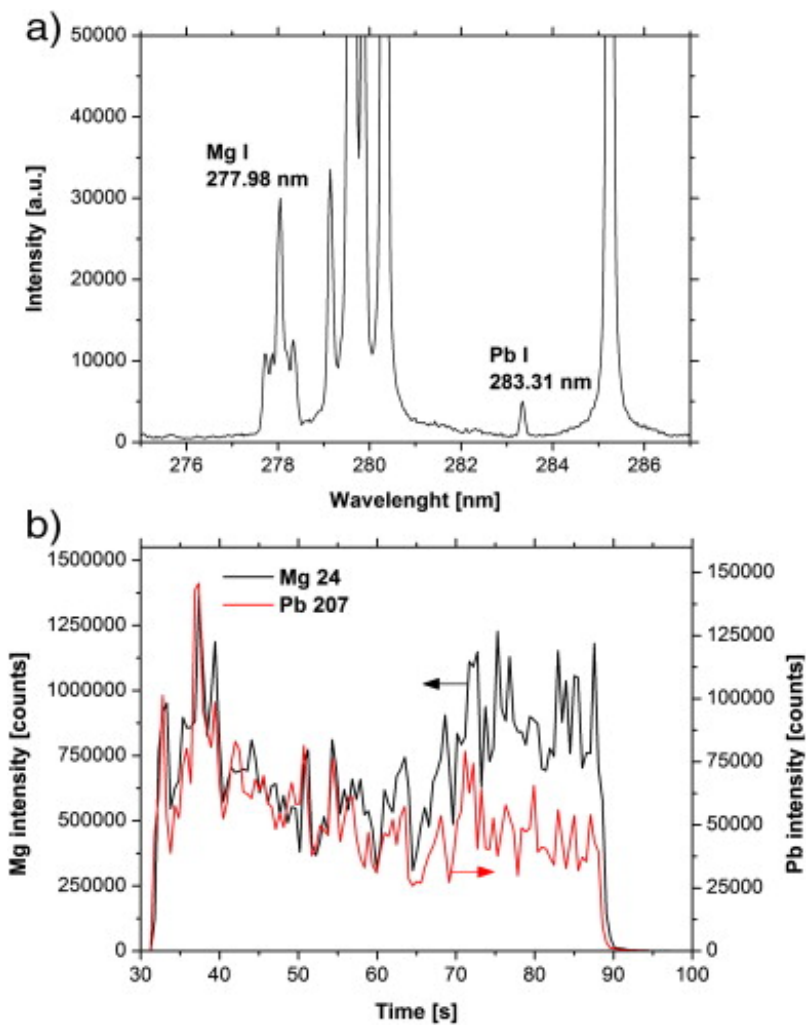

Fig. 2 a) Typical LIBS spectrum with $\mathrm{Mg} I$ line at $277.98 \mathrm{~nm}$ and $\mathrm{Pb} \mathrm{I}$ line at $283.31 \mathrm{~nm}$ used for LIBS analysis and b) section of LA-ICP-MS spectrogram for ${ }^{24} \mathrm{Mg}$ and ${ }^{207} \mathrm{~Pb}$ isotopes. Reproduced from Kaiser et al. ${ }^{49}$ 
conspicuous necrotic changes were identified in plants treated with 500- $\mu \mathrm{M}$ Pb-EDTA (Fig. 1). Single-shot LIBS along with LAICP-MS investigations were conducted on small areas of leaf sections, and the results are shown in Fig. 2. Atomic emission lines appearing at $283.31 \mathrm{~nm}$ and $277.98 \mathrm{~nm}$ were used for $\mathrm{Pb}(\mathrm{I})$ and $\mathrm{Mg}(\mathrm{I})$ detection, respectively.

Owing to its unique properties, LIBS provides instantaneous emission peaks that are directly related to the laser ablation spot. In contrast, LA-ICP-MS does not directly offer information related to a particular location within the sample. The mapping of $\mathrm{Pb}$ and $\mathrm{Mg}$ within the inspected areas is presented in Fig. 3. The laser ablation patterns and the obtained $\mathrm{Pb}$ and $\mathrm{Mg}$ maps are shown for control and $500 \mu \mathrm{M} \mathrm{Pb}$-EDTA-treated plant samples. Using LIBS as well as LA-ICP-MS mapping, the authors were able to image the heterogeneous structures within the leaf and to clearly distinguish between the vein and the surrounding tissues, the latter of which were found to have lower concentrations of the elements of interest. The authors were able to achieve a resolution of up to $\sim 200 \mu \mathrm{m}$ in their LIBS experiment. The crater-sized ablation formed in the LIBS experiment was greater by a factor of $\sim 2$ compared with the crater formed during the LA-ICP-MS measurement. The authors also verified their results by comparing them with data from thin-layer chromatography and atomic absorption spectroscopy (AAS) experiments. Finally, they were able to demonstrate the potential of LA-ICP-MS and LIBS for fast elemental imaging of large-area plant samples.

Galiova et al. studied heavy-metal accumulation in certain varieties of plants using LIBS and LA-ICPMS. ${ }^{50,18}$ The authors explored the feasibility of LIBS to quantify the concentrations of $\mathrm{Ag}, \mathrm{Cu}, \mathrm{Pb}$, and $\mathrm{Mg}$ and their spatial distributions in Helianthus annuus $L$. leaf samples. The overall concentration of the minerals and contaminants within the samples was measured using AAS. The same group explored the application of laser-based analytical techniques to the measurement of $\mathrm{Pb}$ and nutritional minerals in leaf samples of Capsicum annuum L., in order to demonstrate the effect of water content in the leaves. ${ }^{51}$ The authors compared the

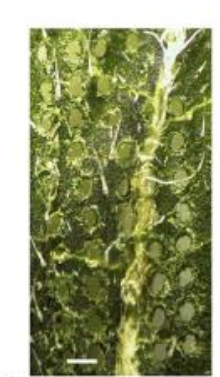

a)

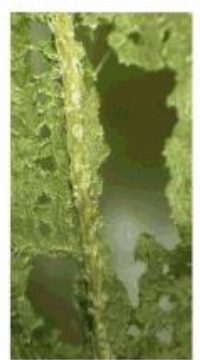

A)

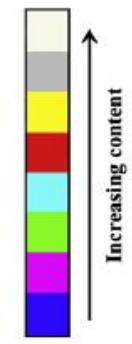

$\mathrm{Mg}$ - LIBS

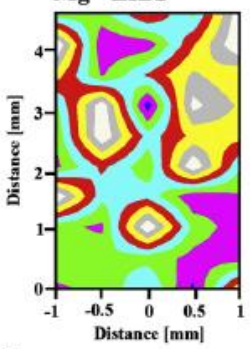

b)
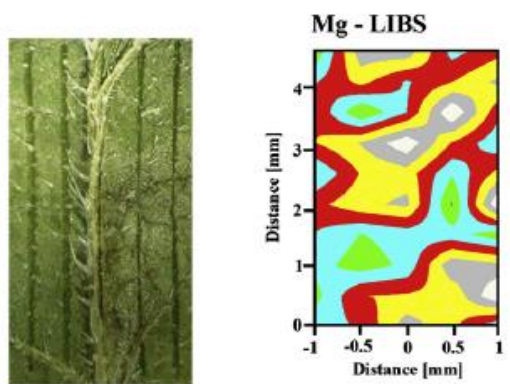

B)

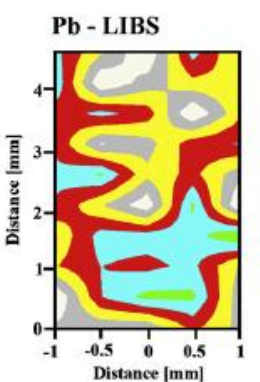

D)

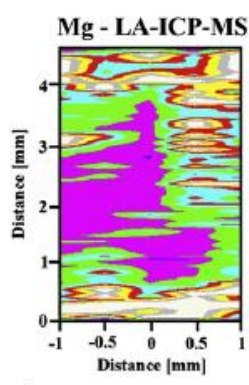

c)

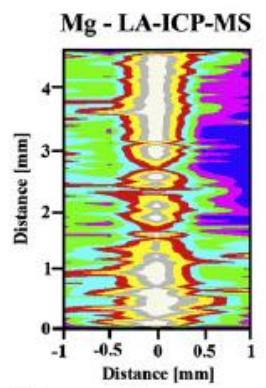

C)

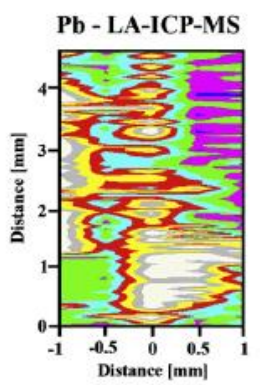

E)

Fig. 3 Demonstration of the mapping potential of LIBS and LA-ICP-MS techniques. a) LIBS (left) and LA-ICP-MS (right) ablation patterns on control sample. b) LIBS-based mapping of Mg and c) LA-ICP-MS-based analysis. A) LIBS (left) and LA-ICP-MS (right) ablation patterns on the sample treated with $500 \mu \mathrm{M}$ Pb-EDTA for 3 days. B) Mapping of Mg applying LIBS and C) applying LA-ICP-MS, D) Pb maps from LIBS and E) LA-ICP-MS analyses. The length of the bar on the image in a) is $500 \mu \mathrm{m}$. Reproduced from Kaiser et al. ${ }^{49}$ 

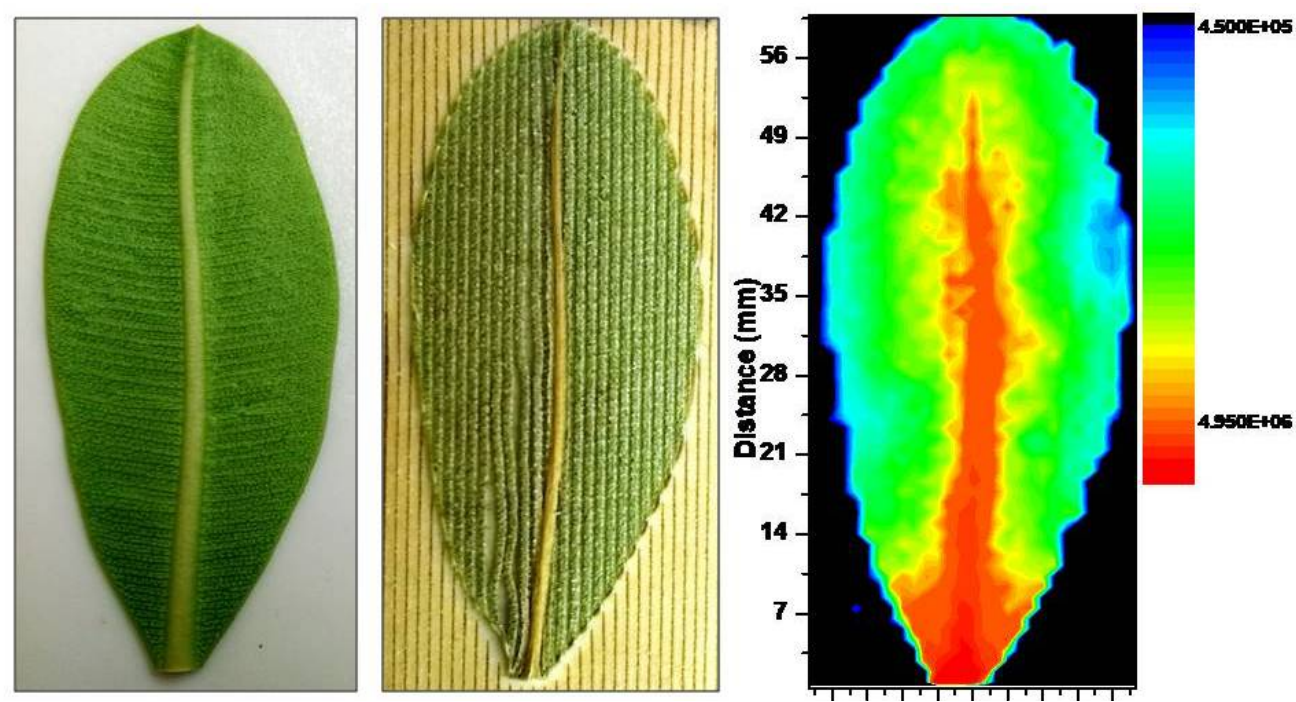

Fig. 4 Images of leaf sample a) before, and b) after LIBS mapping analysis. c) Mapping of Li distribution in LiCl-doped leaf. Reproduced from Singh et al. ${ }^{54}$

elemental imaging of fresh (frozen) and dried leaves. The $\mathrm{Pb}$ imaging obtained using the LIBS and LA-ICP-MS techniques revealed accumulations of $\mathrm{Pb}$ mainly in the central vein, and to a lesser extent in the surrounding areas. In this case, the results obtained via LIBS were confirmed by the LA-ICP-MS results. It was concluded that both fresh and dried samples can be used for monitoring elemental distributions in this plant tissue, because the distributions of the elements of interest were not affected by the drying process in their study.

Recently, Krajcarova et al. used dual-pulse (DP-LIBS) to study the stems of spruce plants and measured the spatial distributions of the constituent elements. ${ }^{52}$ The authors used fluorescence microscopy and compared it with LIBS imaging maps, and the fluorescence intensities were also directly compared with ICP-MS data. The correlations between the results obtained via these methods offered conclusive evidence on the spatial localization of elements within samples. The results also indicated the probability of different uptake mechanisms. Krajcarova et al. also used the LIBS technique to study the uptake of $\mathrm{Cu}$ by $V$. faba and also studied its uptake pathways, translocation, and toxicity. ${ }^{52}$ They mapped the root cross-sections of $V$. faba after exposure to $\mathrm{Cu}^{2+}$ ions for 7 days $\left(10 \mathrm{mM} \mathrm{CuSO}_{4}\right)$. The authors observed the homogeneous distribution of $\mathrm{Cu}$ in $V$. faba root cortex and also the toxic effect of $\mathrm{Cu}$, even at low concentrations.

Martin et al. employed LIBS coupled with multivariate analysis to measure the chemical constituents of annual tree growth rings. ${ }^{53}$ This study compared the elemental and chemical constituents of pre- and post-fire tissue samples. The authors concluded that by studying the elemental and chemical composition pattern of a tree, including any abrupt changes thereof, the interference history of the tree and forest can be reconstructed.

The capability of LIBS was demonstrated recently in the study of Li diffusion in Podocarpus macrophyllus leaves after exposure to $\mathrm{LiCl}$ solution for $8-48 \mathrm{~h} .{ }^{52}$ The authors studied the diffusion of
$\mathrm{Li}$ in plant leaves via their veins and showed that the concentration of $\mathrm{Li}$ in the samples decreases upon moving toward the tip of the leaf. This can be understood by comparing the photographs of the leaf sample before and after laser ablation (Figs. 4a and b) with the two-dimensional (2D) LIBS map (Fig. 4c).

Table 1 provides a list of research conducted on plants using the LIBS technique. ${ }^{2,16,17,18,47,50,53-66}$ Recently, Peng et al. carried out a comparative investigation of the $2 \mathrm{D}$ mapping of $\mathrm{Cr}$ in $O$. sativa leaf samples using SP-LIBS and DP-LIBS. ${ }^{67}$ They found the reheating effect occurring in DP-LIBS allowed the successful imaging of the subcellular location of $\mathrm{Cr}$ in the leaves of $O$. sativa.

\section{ANALYZING MEDICINAL PLANTS USING LIBS}

Minerals are essential for virtually all plant species, including those that are used as fruits, vegetables, medicines, and herbs as well as shrubs. Minerals ensure proper growth, development of various plant tissues, and the proper functioning of the plant, including a healthy metabolism. Mineral analysis in plants during growth is the principal goal of the applications of LIBS in plant science. Micronutrients are present in the range of several to tens of parts per million (ppm) in plants; therefore, a very robust method is necessary for the detection of nutrients in plants at these trace concentrations. Plants obtain these minerals either from soil organic matter or from inorganic fertilizers. ${ }^{68}$ Each plant type is unique, and the optimum amount of mineral nutrients needed for its proper functioning is also unique. If a mineral overdose occurs, plants may suffer from poor growth and various diseases, which may eventually culminate in crop destruction. Revealing details of the transportation of these minerals in different parts of plants is crucial for understanding their functions and metabolic pathways. ${ }^{69}$ The information acquired on the metabolic pathways of plants is potentially very helpful and can be utilized to 


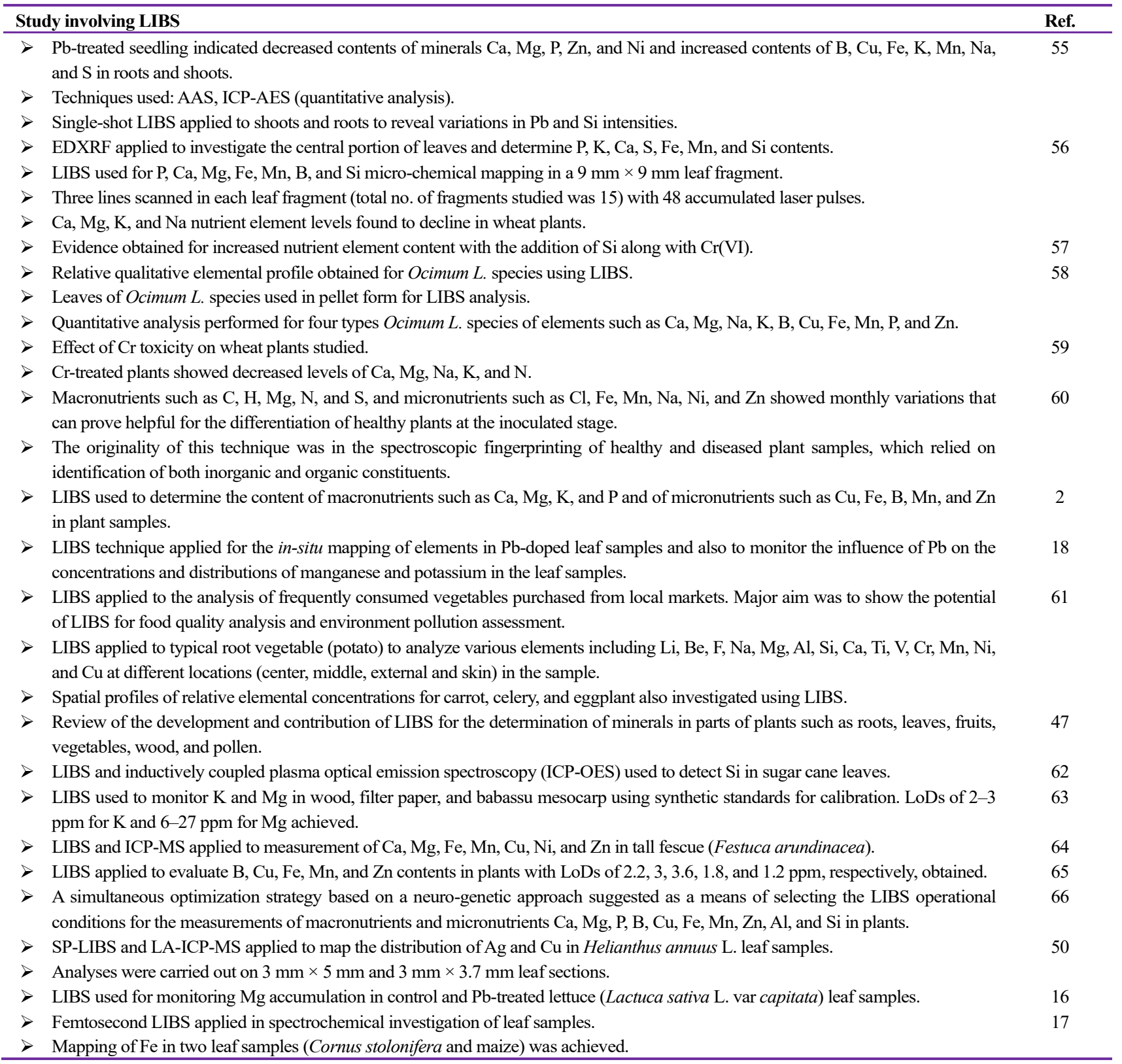

understand the physiology of plants, in addition to being useful in agricultural research associated with agriculture crop plants, genetic studies etc. ${ }^{69}$

A recent review by Lombi et al. covers the application of in-situ conventional techniques to assess the spatial distribution of metals and metalloids in plants. ${ }^{70}$ When a deficiency of essential mineral nutrients occurs, plants suffer from various diseases with symptoms such as the yellowing of leaves, knots on roots, seed galls, and shape deformation. However, many diseases often go unnoticed because the symptoms appear underground and cannot be clearly seen on the plants. Such deficiencies and diseases that cannot be detected in the early stages are known as hidden deficiencies, and the only way to diagnose them is by using advanced analytical methods. Nunes et al. recently used LIBS to examine sugar cane leaves and determined the level of macronutrients such as $\mathrm{Ca}, \mathrm{K}, \mathrm{Mg}$, and $\mathrm{P}$ and micronutrients such as $\mathrm{B}, \mathrm{Cu}, \mathrm{Fe}, \mathrm{Mn}$, and $\mathrm{Zn}$, which all contribute to the composition of healthy sugar cane leaves. ${ }^{71}$ Martin et al. used LIBS for the detection of trace and heavy minerals in a variety of environmental samples. ${ }^{53}$ LIBS was also used to investigate the effect of endophyte (Neotyphodium sp.) infection on the elemental constituents of tall fescue (Festuca arundinacea), and the presence of $\mathrm{Ca}, \mathrm{Cd}, \mathrm{Fe}, \mathrm{Mn}, \mathrm{Mg}, \mathrm{Pb}$, and $\mathrm{Zn}$ in the leaf samples of tall fescue was successfully verified. ${ }^{64}$ Yao et al. applied the LIBS technique to a sample of algae to investigate toxic metal accumulation. ${ }^{72}$

Rai et al. utilized LIBS to measure trace minerals in 
hypoglycemic medicinal plants. ${ }^{26}$ The authors acquired the LIBS spectra of glycemic foods such as C. cajan and Momordica charantia to detect the presence of elements including $\mathrm{Mg}, \mathrm{C}, \mathrm{Ca}$ and $\mathrm{Na}, \mathrm{K}, \mathrm{Mg}, \mathrm{Ca}, \mathrm{Fe}$, and Al. They used the CF-LIBS method to quantify the contents of the trace elements present in these food items. M. oleifera and E. officinal fruit extracts were tested using LIBS analysis, and the spectra revealed the presence of $\mathrm{Mg}, \mathrm{Ca}, \mathrm{H}$, $\mathrm{C}, \mathrm{O}$, and $\mathrm{N}$ in both these medicinal plants.

Recently, Andrade et al. applied LIBS and ICP-OES to the measurement of essential and toxic metals in some medicinal herbs. ${ }^{73}$ The elements detected and quantified were $\mathrm{Ca}, \mathrm{Co}, \mathrm{Cu}$, $\mathrm{Cd}, \mathrm{Cr}, \mathrm{Fe}, \mathrm{Mg}, \mathrm{Mn}, \mathrm{Na}, \mathrm{Ni}, \mathrm{Pb}$, and $\mathrm{Zn}$. The analyzed samples were all herbs belonging to a particular species and constituted different morphological plant parts. The morphological differences were correlated with different characteristic distributions in the 2D score plots acquired using PCA. The authors reported a strong correlation between LIBS and ICP-OES results, particularly with respect to the $\mathrm{Ca}, \mathrm{K}$, and $\mathrm{Mg}$ content.

Tripathi et al. applied two efficient approaches, namely LIBS and inductively coupled argon plasma atomic emission spectroscopy (ICAP-AES), in a recent investigation of the elements in Ocimum L., ${ }^{57,58}$ which is regarded as one of the most important herbs worldwide due to its medicinal importance and potential therapeutic applications. ${ }^{74}$ The present LIBS study was directed toward determining the elemental constituents in leaf samples of Ocimum species, viz., Ocimum basilicum, Ocimum sanctum, Ocimum gratissimum, and Ocimum americanum. LIBS studies have been performed on different Ocimum leaves in order to investigate the contents of the mineral elements $\mathrm{Ca}, \mathrm{K}, \mathrm{Mg}, \mathrm{Na}$, and $\mathrm{Si}$ as well as those of the lighter elements $\mathrm{C}, \mathrm{H}, \mathrm{O}$, and $\mathrm{N}$; the results were reproduced by ICP-AES experiments. The authors also confirmed the pattern of elemental content using an intensity ratio method, as depicted in Fig. 5. Fig. 5 indicates the ratio of detected minerals in wild and cultivated Ocimum species. It is apparent that $\mathrm{Ca}, \mathrm{Mg}$, and $\mathrm{Na}$ were present in greater concentrations in $O$. sanctum than in $O$. basilicum, while moreK was detected in $O$. basilicum than in $O$. sanctum. The larger percentages of $\mathrm{C}, \mathrm{H}, \mathrm{N}$, and $\mathrm{O}$ in $O$. sanctumcompared with $O$. Basilicum indicates a relatively greater number of organic constituents in the former. In addition, $\mathrm{Ca}$ and $\mathrm{Mg}$ were found in greater concentrations in $O$. gratissimum and in lower concentrations in $O$. americanum. In contrast, higher concentrations of $\mathrm{Na}, \mathrm{K}, \mathrm{N}, \mathrm{O}$, and $\mathrm{H}$ were found in $O$. americanum compared with those in $O$. gratissimum (Fig. 5). PCA was also applied successfully to distinguish the wild species from the cultivated ones. The authors were able to confirm the suitability of the LIBS technique as a non-destructive and ecofriendly approach to plant analysis.

Ercioglu et al. recently used LIBS to distinguish some aromatic plants including laurel, basil, black pepper, lavender, and ginger based on their chemical compositions. ${ }^{75}$ Using their results, the
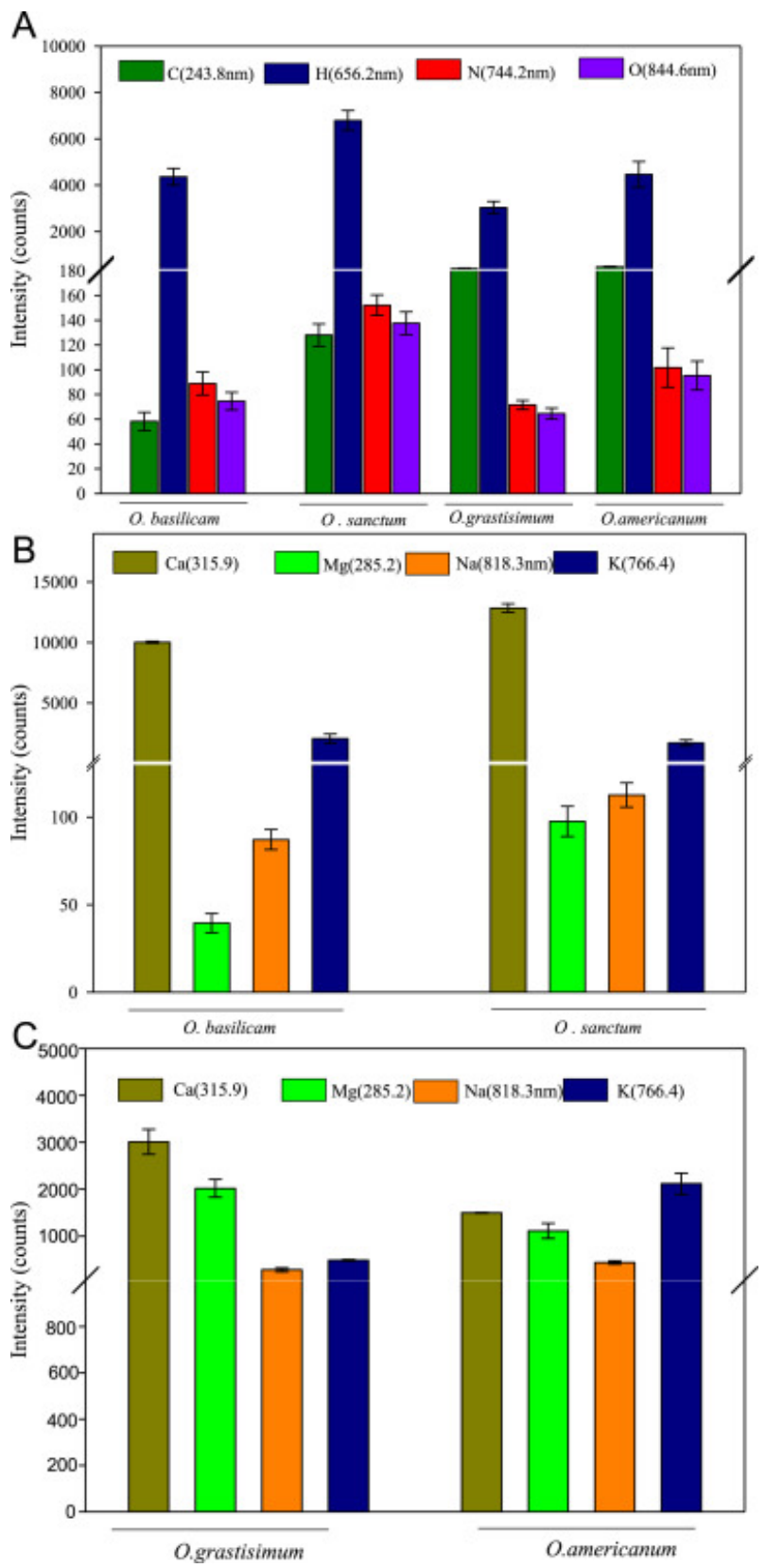

Fig. 5 Average intensity ratios (concentrations) for elements in the LIBS spectra of Ocimum leaves (in pellet form) after focusing the laser beam (AC). Adapted from Tripathi et al. ${ }^{58}$

authors were able to rapidly discriminate between these culinary herbs, owing to the combination of the LIBS technique with PCA. This outcome is very relevant in the context of the aromatic plant industry, as it leads to the possibility of the development of protocols for characterizing raw materials for quality control purposes. Zivkovic et al. observed the presence of elements including $\mathrm{Al}, \mathrm{Ca}, \mathrm{Cu}, \mathrm{Mn}, \mathrm{Ba}, \mathrm{K}$, and $\mathrm{Sr}$ in peppermint tea samples using the LIBS technique. ${ }^{76}$ Using a calibration curve method, they could accurately measure the concentrations of $\mathrm{Mn}$ and $\mathrm{Ba}$ (regression coefficient, $R^{2}>0.95$ ). 
Table 2. Application of LIBS to Detection of Mineral Elements in Various Plant Species, Including Medicinal Plants

\begin{tabular}{llc}
\hline Plant species & Elements & Ref. \\
\hline Algal (Trachydiscus minutus) & $\mathrm{Ca}, \mathrm{K}, \mathrm{Na}, \mathrm{Mg}, \mathrm{Cu}$ & 77 \\
Bermuda Grass (Cynodon dactylon) & $\mathrm{Al}, \mathrm{Mg}, \mathrm{Ca}, \mathrm{C}, \mathrm{Sr}$, & 78 \\
& $\mathrm{Si}, \mathrm{Zn}$ & \\
Boldo (Peumus boldus) & $\mathrm{Mn}, \mathrm{Zn}, \mathrm{B}, \mathrm{Fe}, \mathrm{Cu}$ & 65 \\
Brachiaria (Brachiaria decumbens) & $\mathrm{Cu}, \mathrm{Mn}, \mathrm{Zn}, \mathrm{Fe}, \mathrm{B}$ & 65 \\
Coffee (Coffea arabica) & $\mathrm{B}, \mathrm{Cu}, \mathrm{Fe}, \mathrm{Mn}, \mathrm{Zn}$ & 65 \\
Cotton & $\mathrm{Al}, \mathrm{Ba}, \mathrm{Ca}, \mathrm{Cu}, \mathrm{Cr}$, & 79 \\
& $\mathrm{Fe}, \mathrm{Mg}, \mathrm{Sr}$ \\
Endive (Cichorium endivia) & $\mathrm{B}, \mathrm{Cu}, \mathrm{Fe}, \mathrm{Mn}, \mathrm{Zn}$ & 65 \\
Grass (Axonopus obtusifolius) & $\mathrm{B}, \mathrm{Cu}, \mathrm{Fe}, \mathrm{Mn}, \mathrm{Zn}$ & 65 \\
Jack (Artocarpus integrifolia) & $\mathrm{B}, \mathrm{Cu}, \mathrm{Fe}, \mathrm{Mn}, \mathrm{Zn}$ & 65 \\
Longleaf pine tree (Pinus palustris) & $\mathrm{Ca}, \mathrm{Fe}, \mathrm{Na}, \mathrm{S}$ & 53 \\
Mango (Mangifera indica) & $\mathrm{B}, \mathrm{Cu}, \mathrm{Fe}, \mathrm{Mn}, \mathrm{Zn}$ & 65 \\
Oranges (Citrus sinensis) & $\mathrm{Ca}, \mathrm{C}, \mathrm{Cl}, \mathrm{H}, \mathrm{Fe}$, & 60 \\
& $\mathrm{Mg}, \mathrm{Mn}, \mathrm{Ni}, \mathrm{N}, \mathrm{O}$, & \\
Poplar tree & $\mathrm{K}, \mathrm{S}, \mathrm{Na}, \mathrm{Zn}$ & \\
& $\mathrm{N}, \mathrm{P}, \mathrm{K}, \mathrm{Ca}, \mathrm{Fe}, \mathrm{Ti}$, & 80 \\
Red osier dogwood & $\mathrm{Mn}, \mathrm{Na}$ \\
(Cornus stolonifera) & $\mathrm{Fe}$ \\
Sophora & \\
(Styphnolobium japonicum) & $\mathrm{Ca}$ \\
Spruce & & \\
Tall fescue (Festuca arundinacea) & $\mathrm{Ca}, \mathrm{Cu}, \mathrm{Ca}, \mathrm{Fe}, \mathrm{Pb}, \mathrm{Mn}$, & 64 \\
Tobacco & $\mathrm{Mg}, \mathrm{Zn}$ \\
& $\mathrm{Fe}, \mathrm{Ca}, \mathrm{Al}, \mathrm{Cu}, \mathrm{K}$, & 82 \\
& $\mathrm{Li}, \mathrm{Mg}, \mathrm{Mn}, \mathrm{Na}, \mathrm{Sr}$, \\
& $\mathrm{Ti}, \mathrm{Zn}$ & \\
\hline
\end{tabular}

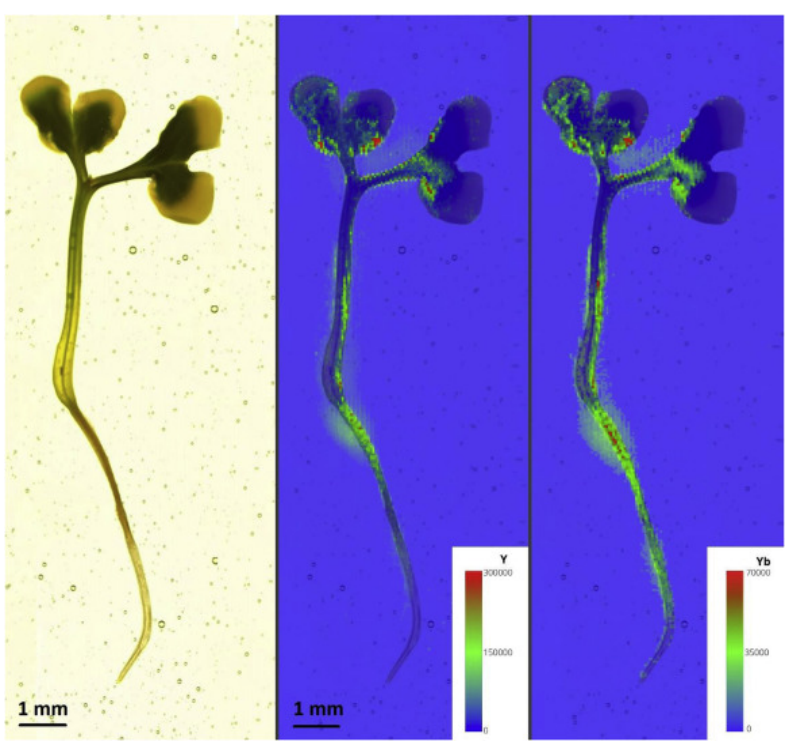

Fig. 6 Spatial distribution of $\mathrm{Y}$ and $\mathrm{Yb}$ in Raphanus sativus. Adapted from Modlitbova et al. $^{35}$

Table 2 lists some recent studies that used LIBS for mineral detection in plants of medicinal importance or of importance within the context of plant science. ${ }^{17,51,53,60,64,65,77,78,79,80,81,82}$ LIBS has been used extensively to study almost all trace metals and non- metal elements in different plant matrices, and it can be used in the pharmaceutical industry to study the glycemic components of medicinal plants.

\section{VISUALIZATION OF NANOPARTICLES IN PLANT MATERIALS USING LIBS}

In the last few years, the LIBS research community has focused on the production of new nanomaterials and their application in plant and agricultural sciences. However, little data are available in the literature regarding the distributions of nanoparticles (NPs) in plants. Therefore, a novel analytical tool is crucial for providing spatial distributions of NPs in plant materials and for generating complete large-scale images of model organisms. To date, very few applications of LIBS for the detection of NPs have been reported, particularly in plants. ${ }^{83}$ Very recently, LIBS has been used to study $\mathrm{Ag} \mathrm{NPs},{ }^{52} \mathrm{CdTe} \mathrm{NPs},{ }^{84}$ and photon-upconversion $\mathrm{NPs}^{35}$ and their distributions in aquatic (L. minor) and terrestrial ( $V$. faba, R. sativus) plants. The use of the LIBS method to visualize NPs in plant tissues was first reported by Krajcarova et al. in $2017 .{ }^{52}$ In this study, the authors observed significant differences between the distributions of $\mathrm{Ag}^{+}$ions and Ag NPs in $V$. faba roots, which were acquired with a resolution of $50 \mathrm{~mm}$. They observed the localization of Ag NPs in particular root sections; however, the $\mathrm{Ag}^{+}$ions were distributed homogenously across the entirety of the root system. This study also revealed information about the low NP uptake rate that was in good agreement with the current literature. ${ }^{85,86}$

Modlitbova et al. carried out an investigation to study Cd spatial distributions originating principally from NPs capped with glutathione, CdTe NPs capped with 3-mercaptopropionic acid, and $\mathrm{CdCl}_{2}{ }^{84}$ The authors carried out the TEM analysis of the leaves in order to confirm that the plants did not absorb the NPs. Furthermore, 2D LIBS mapping revealed no differences in the $\mathrm{Cd}$ distributions originating from NPs and $\mathrm{CdCl}_{2}$.

In 2019, Modlitbova et al. performed an extensive study using LIBS to visualize the distribution of $\mathrm{Y}$ and $\mathrm{Yb}$ originating from photon up-conversion NPs ( $\left.\mathrm{NaYF}_{4}: \mathrm{Yb}^{3+}, \mathrm{Er}^{3+}-\mathrm{SiO}_{2}-\mathrm{COOH} \mathrm{NPs}\right)$ in L. minor and R. sativus plants (Fig. 6) ${ }^{35}$ They found a spatial resolution of $100 \mathrm{~mm}$ to be sufficient for imaging $\mathrm{Y}$ and $\mathrm{Yb}$ across the entire plant sample. The authors detected the existence of the NPs and their translocation from the roots into the leaves, which was verified via photon up-conversion scans. Finally, the authors showed the importance and significant potential of NPs, on account of their stability, moderate toxicity, and bioaccumulation, compared with the ionic forms of $\mathrm{Y}$ and $\mathrm{Yb}$.

To a certain limited extent, a few research groups have applied the LIBS technique for imaging chemical constituents in biotic tissues. ${ }^{34,87}$ For example, the in-situ distribution of the pesticide 
chlorpyrifos was analyzed by one group via $\mathrm{P}$ and $\mathrm{Cl}$ imaging in Z. mays leaf samples using a LipsImag apparatus. ${ }^{34}$ They also studied A. schoenoprasum plant samples in the laboratory with NELIBS. ${ }^{87}$

Zhao et al. proved the in-situ capability of LIBS for the elemental mapping of plant leaves after pesticides were sprayed on the leaves. ${ }^{34}$ Further, they performed a NELIBS analysis to obtain spatially resolved data and signal enhancement; ${ }^{87}$ the authors sprayed Ag NPs onto the leaves of A. schoenoprasum to enhance the $\mathrm{P}$ and $\mathrm{Cl}$ signals.

\section{LIBS ANALYSIS OF FOOD AND AGRICULTURAL PRODUCTS}

With the recent developments in the LIBS technique, in terms of instrumentation and methodological approach, the use of LIBS for the analysis of samples of complex matrices in agricultural science has become possible. Here, we summarize some of the recent progress in heavy and toxic and mineral element measurement, particularly in plant and agricultural samples. The diverse application of LIBS to agricultural science has been reviewed by Peng et al. ${ }^{28}$ The use of LIBS and its practical applications in the field of agriculture are not restricted to the previously mentioned aspects. However, here, for the sake of brevity, we limit our summary to the reports of work using LIBS in key research areas.
Significant research effort has been devoted to the careful but rapid examination of agricultural food stuffs via the use of analytical methods with fewer preparation steps. ${ }^{88}$ Being an advanced analytical tool, LIBS serves as a powerful technique in detecting nutritional and heavy-metal elements in agricultural and food products. ${ }^{88}$ Kim et al. were the first to report the successful application of the LIBS technique to measure agricultural pesticide residue, ${ }^{89}$ and since then, this approach has received ever increasing attention owing to its versatility. The authors adopted LIBS for investigating spinach and rice samples, to detect the presence of important elements $(\mathrm{Mg}, \mathrm{Ca}, \mathrm{Na}, \mathrm{K})$ that allow the differentiation of pesticide-contaminated samples from healthy or reference samples. CF-LIBS was used to measure the concentrations of the elements. ${ }^{89}$

Determination of nutritional balance in agricultural products is very important to ensure that the human body does not have a deficit of the important minerals that are found in agricultural products consumed regularly as part of our diet. ${ }^{89}$ Alfarraj et al. reported the elemental composition of dairy and milk products by using a LIBS analysis. ${ }^{90}$ The authors used a PCA method to distinguish soy, milk powder, dairy milk, and lactose-free dairy milk based on their elemental compositions. $\mathrm{Ca}, \mathrm{K}, \mathrm{Mg}$, and $\mathrm{Na}$ atomic lines were observed in the spectra of all the four specimens; however, the concentrations of these elements differed in each specimen.

Recently, the 3D mapping capability of LIBS, without any
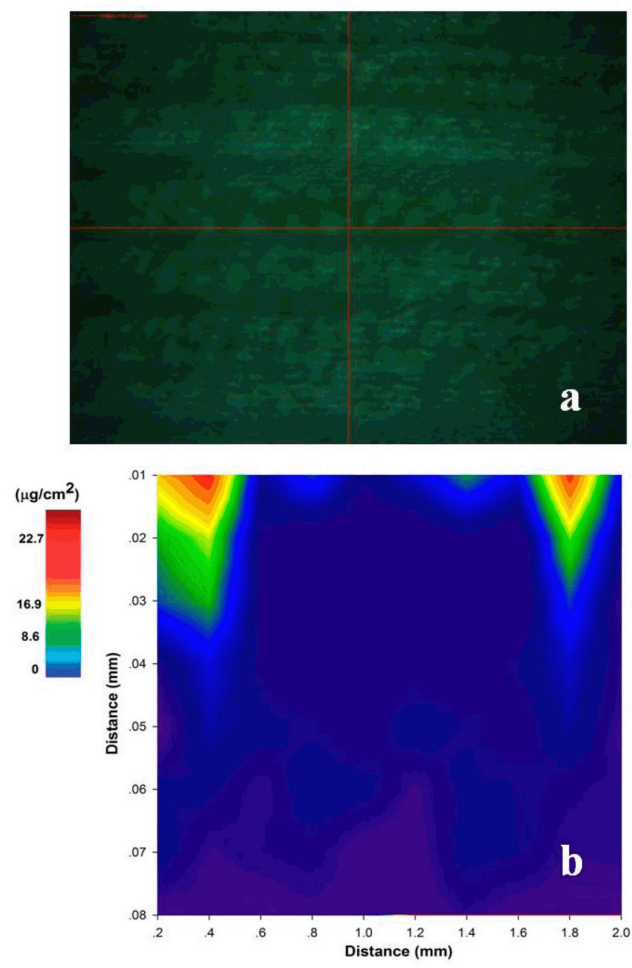

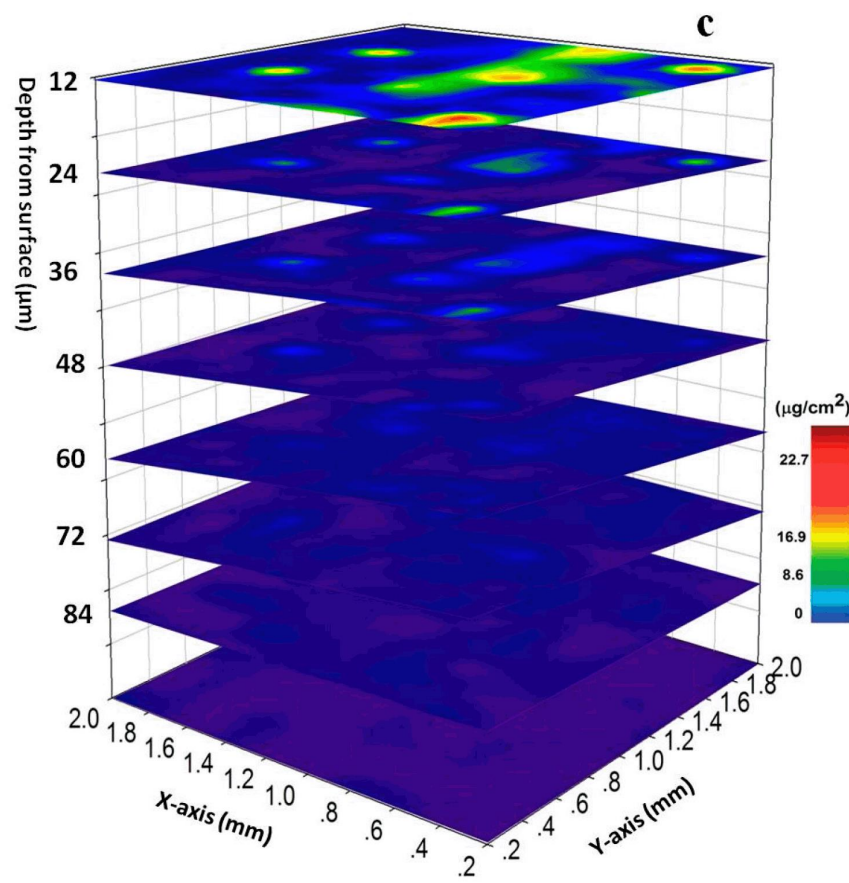

Fig. 7 Three-dimensional mapping of pesticide residues in a maize leaf $10 \mathrm{~h}$ after spraying. a) Visible-light microscopy image of the scanning area. b) Crosssectional image showing the pesticide distribution in an axial plane. c) Three-dimensional image of pesticide residue acquired by scanning individual planes sequentially; the interval between each lateral plane is $12 \mu \mathrm{m}$. Adapted from Zhao et al. ${ }^{34}$ 
Table 3. Application of LIBS to Elemental Analysis of Agricultural Food Stuffs

\begin{tabular}{lll}
\hline Agricultural food products & Elements analyzed & Ref. \\
\hline Bean (Pulses) & $\mathrm{Ca}$, & 65 \\
Pepper (Capsicum annum $\mathbf{L}$ ) & $\mathrm{Pb}, \mathrm{Mn}, \mathrm{K}$ & 51 \\
Chickpea & $\mathrm{Si}, \mathrm{Mg}, \mathrm{Ti}, \mathrm{Fe}, \mathrm{Ca}, \mathrm{C}, \mathrm{Al}$ & 91 \\
Fenugreek seeds & $\mathrm{Si}, \mathrm{Mg}, \mathrm{Ti}, \mathrm{Fe}, \mathrm{Ca}, \mathrm{C}, \mathrm{Al}$ & 91 \\
Folium Lycii & $\mathrm{Al}, \mathrm{Ca}, \mathrm{K}, \mathrm{Li}, \mathrm{Mg}, \mathrm{Na}, \mathrm{Si}, \mathrm{Sr}$, & 92 \\
& $\mathrm{Ti}$ & \\
Leaf mustard & $\mathrm{Si}, \mathrm{Mg}, \mathrm{Ti}, \mathrm{Fe}, \mathrm{Ca}, \mathrm{C}, \mathrm{Al}$ & 91 \\
Lettuce (Lactuca sativa) & $\mathrm{Fe}, \mathrm{Mn}, \mathrm{B}, \mathrm{Cu}, \mathrm{Zn}$ & 65 \\
Maize (Zea mays) & $\mathrm{B}, \mathrm{Fe}, \mathrm{Cu}, \mathrm{Zn}, \mathrm{Mn}$ & 65 \\
Pepper (Piper nigrum) & $\mathrm{B}, \mathrm{Cu}, \mathrm{Fe}, \mathrm{Mn}, \mathrm{Zn}$ & 65 \\
Potato (Solanum tuberosum) & $\mathrm{Al}, \mathrm{Ba}, \mathrm{Be}, \mathrm{Ca}, \mathrm{C}, \mathrm{Cl}, \mathrm{Cr}$, & 93 \\
& $\mathrm{Co}, \mathrm{Cu}, \mathrm{Fe}, \mathrm{H}, \mathrm{K}, \mathrm{Li}, \mathrm{Mn}$, \\
& $\mathrm{Mg}, \mathrm{Mo}, \mathrm{N}, \mathrm{Na}, \mathrm{Ni}, \mathrm{V}, \mathrm{O}$, \\
Soya (Glycine max) & $\mathrm{Rb}, \mathrm{Si}, \mathrm{Sr}, \mathrm{S}, \mathrm{Ti}$ & \\
Spinach (Spinacia oleracea) & $\mathrm{Fe}, \mathrm{Cu}, \mathrm{Mn}, \mathrm{Zn}, \mathrm{B}$ \\
& $\mathrm{Ca}, \mathrm{Mg}, \mathrm{P}, \mathrm{B}, \mathrm{Cu}, \mathrm{Fe}, \mathrm{Mn}$, & 66 \\
Sugarcane & $\mathrm{Zn}, \mathrm{Al}, \mathrm{Si}$ \\
& $\mathrm{B}, \mathrm{Ca}, \mathrm{Cu}, \mathrm{Fe}, \mathrm{K}, \mathrm{Mg}, \mathrm{Mn}, \mathrm{P}$, & 66 \\
Sunflower & $\mathrm{Zn}$ \\
(Helianthus annuus) & $\mathrm{Ag}, \mathrm{Ca}, \mathrm{Cu}, \mathrm{K}, \mathrm{Mn}, \mathrm{Mg}, \mathrm{Pb}$ & 94 \\
Wheat seedling & $\mathrm{C}, \mathrm{Ca}, \mathrm{Fe}, \mathrm{H}, \mathrm{K}, \mathrm{Mg}, \mathrm{N}, \mathrm{Na}$, & 25 \\
& $\mathrm{O}, \mathrm{Si}$ \\
\hline
\end{tabular}

sample preparation, was demonstrated. ${ }^{34}$ This type of study is very relevant for investigating biological samples with heterogeneous mineral distributions. The authors performed this in-situ and in vivo $3 \mathrm{D}$ elemental mapping study using a field-portable LIBS system in a maize field. An organophosphorus pesticide (chlorpyrifos, $\mathrm{C}_{9} \mathrm{H}_{11}-\mathrm{Cl}_{3} \mathrm{NO}_{3} \mathrm{PS}$ ) was sprayed on a maize leaf, and the vegetal tissue was subsequently investigated $10 \mathrm{~h}$ after the exposure. Combining their LIBS investigation with multivariate regression models, the authors were able to accurately detect the pesticide residues. The obtained 3D LIBS maps (reproduced in Fig. 7), which were obtained by using a step in the axial direction of 12 $\mu \mathrm{m}$, clearly illustrating a pattern of diminishing pesticide residues along the leaf depth. That study extended the scope of LIBS, presenting it as a new elemental mapping technology, comparable to X-ray microscopy and mass spectroscopy-based techniques, owing to its portability for field measurements of living plants. Indeed, this was the first time that in-situ and in vivo LIBS were applied to the elemental imaging of plants. The spatial resolution reported for this work was $200 \mu \mathrm{m}$, which is lower than that achievable in conventional synchrotron radiation-XRF (SRXRF) and secondary ion mass spectrometry techniques.

Micro-chemical imaging of vegetal tissues also furnishes valuable information on plant nutrition and diagnosis, particularly if direct measurement of macronutrients and micronutrients is available. Recently, Guerra et al. performed mapping of $\mathrm{P}, \mathrm{Ca}, \mathrm{Mg}$, $\mathrm{Fe}, \mathrm{Mn}, \mathrm{B}$, and $\mathrm{Si}$ in dried sugar cane leaf fragments by employing the LIBS technology. ${ }^{56}$ The authors used both EDXRF and LIBS systems to study the spatial distributions of these mineral elements over the surfaces of the leaf samples.
Table 3 lists some applications of LIBS to agricultural

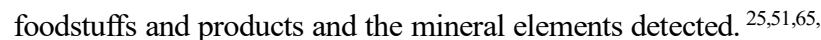
$66,91,92,93,94$

\section{SOIL COMPOSITIONAL ANALYSIS USING LIBS}

At the global level, agricultural analytics are key to the management of the growing fundamental demand for food, animal feed, and water. Soil is the primary component of modern agriculture, providing all the mineral nutrients for plants to grow. Heavy and toxic elements such as $\mathrm{Ba}, \mathrm{Co}, \mathrm{Cd}, \mathrm{Cr}, \mathrm{Hg}, \mathrm{Pb}, \mathrm{Mo}$, and $\mathrm{Sb}$ reach the soil as a result of environmental contamination by various pathways, and they are subsequently absorbed by plants, which ultimately leads to potential adverse and hazardous consequences for human health. ${ }^{28}$ The use and discharge of fertilizers, pesticides, sewage waste, solid waste, and irrigation water, along with chemical emissions from industry and roads, are the most common origins of heavy and toxic metals in soil. ${ }^{95}$ Considering the vast spectrum of threats, including population growth, food security, hazardous chemical pesticides, degradation of the natural environment, and climate change, accurate measurements that allow the control and prevention of soil contamination by heavy-metal elements and organic matter is a major concern in modern agricultural sciences. The LIBS technique is at present being used to detect heavy metals in soil. ${ }^{96}$ LIBS has been extensively applied to monitor soil mineral content and soil contamination. ${ }^{97,98}$ Badday et al. recently used a LIBS technique to provide quantitative measurements of heavy element content, including $\mathrm{Ag}, \mathrm{Cu}, \mathrm{Cd}, \mathrm{Cr}, \mathrm{Hg}, \mathrm{Mo}, \mathrm{Ni}, \mathrm{Pb}$, and $\mathrm{Zn}$ contents, in soil and validated the results obtained with data acquired from flame-AAS (FAAS). ${ }^{99}$ They also used the LIBS technique to monitor traces of the essential minerals $\mathrm{C}, \mathrm{Ca}, \mathrm{Ba}, \mathrm{K}, \mathrm{Mg}, \mathrm{N}, \mathrm{P}$, and $\mathrm{Zn}$ in soil.

The most important elements in soil are $\mathrm{C}$ and $\mathrm{N}$, and these can be quantified using suitable spectroscopic techniques. Nguyen et al. used two C emission lines (247.86 nm and $193.03 \mathrm{~nm}$ ) for the quantitative measurement of the carbon content of soil and concluded that both lines provided good linear calibration curves. ${ }^{100}$ Although measuring the $\mathrm{N}$ level in soil is somewhat challenging due to the large amount of atmospheric $\mathrm{N}$, some reports have been published regarding its detection in soil. Ronny et al. used LIBS to measure the N, S, and P contents of soil under vacuum, using an argon purge system and optimizing the instrumentation for each specific element. ${ }^{101}$ Capetelli et al. applied the LIBS method to determine heavy-metal elements in soil. ${ }^{95}$ Their results were found to be adequate for the qualitative detection of heavy metals in the soil. Haddad et al. documented the in-situ investigation of $\mathrm{Pb}$ in soil by using a LIBS method. ${ }^{102}$

Senesi et al. employed a LIBS technique to determine the elemental constituents of plants and composts used for soil 
remediation. The authors detected several elements including $\mathrm{Al}$, $\mathrm{Ca}, \mathrm{Cr}, \mathrm{Cu}, \mathrm{Fe}, \mathrm{K}, \mathrm{Mg}, \mathrm{Mn}, \mathrm{Na}, \mathrm{Pb}, \mathrm{Sr}$, and $\mathrm{Zn}$, in two composts of different origin and four accumulator plant species (Atriplex halimus, Brassica alba, Brassica napus, and Eruca vesicaria). ${ }^{103}$ They also verified their LIBS concentration results with ICP-OES measurements. These authors proved the feasibility of LIBS for fast elemental screening of plant and compost samples. In 2019 , Senesi et al. published an extensive review on the applications of LIBS techniques, particularly to crop plants and food derivatives, outlining the major studies published in the last decade (2010 2019). ${ }^{104}$ They provided an extensive discussion on the recent developments in LIBS, including micro-LIBS, NELIBS, and 3D elemental imaging for the study of agricultural materials. Finally, they highlighted novel trends for the future advancement of LIBS as an efficient physical tool in plant and agricultural science that facilitates the analysis of any type of plant species and its derivatives. The reviewed literature indicated that LIBS has been used successfully to analyze soil and hence to monitor environmental toxicity for agricultural purposes. Thus, it is apparent that the performance of the LIBS technique is improving, and ever more attention is being focused on its applications in the field of agricultural and plant sciences.

\section{SUMMARY AND OUTLOOK}

With recent advancements, LIBS has been developed into a very robust tool, especially in the field of plant science where multielemental analyses of very complex compounds are always critical in the search to obtain the best products. This article reviewed all the findings that have been reported in the field of plant science and discussed the future prospects for this field and the potential for developments that will ensure the viability and versatility of LIBS as a practical tool.

We highlighted the current state-of-the-art in the field of applied LIBS for plant and agricultural sciences, including data processing methods such as CF-LIBS and multivariate analysis coupled with LIBS. LIBS is a growing technology in plant science, and it is currently being used extensively for the rapid measurement and imaging of heavy and nutrient minerals in plants species, food products, agricultural products, and soil. We also presented a comprehensive review of recent papers reporting the use of DPLIBS as a signal enhancement method in plant science. Recent progress in plant science using CF-LIBS, univariate analysis, and multivariate analysis to diminish serious matrix effects in plant and soil samples is also summarized.

While the LIBS technique has numerous advantages in the elemental analysis of all types of samples, including plant samples, it also has some drawbacks. The lateral spatial resolution available for LIBS elemental mapping is much lower than those of other analytical methods that use electron beams, such as SEM-EDS. ${ }^{105}$ The dimension of the ablation crater places a severe limitation on the spatial resolution. In addition, the analytical performance, precision, and repeatability of the analytical result are generally inferior to those of other types of plasma spectrometry, for instance, laser ablation ICP-MS. ${ }^{106}$

For further practical applications and improvements in LIBS techniques for plant science, some additional methodology developments may be suggested. For example, the use of chemometric methods in LIBS to acquire exact information should facilitate improvements in calibration performance and hence also in classification. Chemometrics coupled with LIBS will also play a key role in plant science, allowing better interpretation and understanding of experimental results. Furthermore, the potential for the interpretation of results from a fundamental physical or chemical viewpoint and the analytical capabilities are expected to be significantly enhanced when LIBS is coupled with ICP-MS, near-IR spectroscopy, Raman spectroscopy, and developing sensing technologies. This should also lead to the development of new field-portable LIBS sensors for agricultural purposes. The evolution of stand-off and field-portable LIBS technology will ultimately bring real practical applicability to the field of LIBS research, providing more compact and robust instrumentation. In conclusion, LIBS will play a more significant role in the future in agriculture, with the development of an increasing number of new instrumentation and analytical approaches.

\section{AUTHOR INFORMATION}

\section{Corresponding Author}

*V. K. Singh

Email address: vivekksingh2005@gmail.com

Notes

The authors declare no competing financial interest.

\section{ACKNOWLEDGMENTS}

N. Sharma is thankful to the Department of Science and Technology (DST) of the Government of India for providing financial support (INSPIRE Reg. No. IF160893).

\section{REFERENCES}

1. B. Wu and S. J. Becker, Metallomics, 2012, 4, 403-416. https://doi.org/10.1039/C2MT00002D

2. M. D. S. Gomes, J. D. Santos, L. C. Nunes, G. G. A. Carvalho, F. O. Leme, and F. J. Krug, Talanta, 2011, 85, 1744-1750. https://doi.org/10.1016/j.talanta.2011.06.069

3. S. Clemens, Biochimie., 2006, 88, 1707-1719. http://dx.doi.org/10.1016/j.biochi.2006.07.003 
4. S. Pokrant, M. Cheynet, S. Jullian, and R. Pantel, Ultramicroscopy, 2005, 104, 233-243. https://doi.org/10.1016/j.ultramic.2005.05.001

5. K. Novotny, T. Vaculovic, M. Galiova, V. Otruba, V. Kanicky, J. Kaiser, M. Liska, O. Samek, R. Malina, and K. Palenikova, Appl. Surf. Sci., 2007, 253, 3834-3842. https://doi.org/10.1016/j.apsusc.2006.08.047

6. K. Flynn, R. O'Leary, C. Roux, and B. J. Reedy, J. Forensic Sci., 2006, 51, 586-596. http://hdl.handle.net/10453/3531

7. O. Samek, D. C. S. Beddows, H. H. Telle, J. Kaiser, M. Liska, J. O. Caceres, and A. G. Urena, Spectrochim. Acta B, 2001, 56, 865-875. https://doi.org/10.1016/S0584-8547(01)00198-7

8. J. F. Adam, J. P. Moy, and J. Susini, Rev. Sci. Instrum., 2005, 76, 09130. https://doi.org/10.1063/1.2018633

9. L. Reale, A. Lai, I. Bellucci, A. Faenov, T. Pikuz, F. Flora, L. Spano, A. Poma, T. Limongi, L. Palladino, A. Ritucci, G. Tomassetti, G. Petrocelli, and S. Martellucci, Microsc. Res. Tech., 2006, 69, 666-674. https://doi.org/10.1002/jemt.20041

10. J. Kaiser, L. Reale, A. Ritucci, G. Tomassetti, A. Poma, L. Spano, A. Tucci, F. Flora, A. Lai, F. Faenov, T. Pikuz, L. Mancini, G. Tromba, and F. Zanini, Eur. Phys. J. D., 2005, 32, 113-118. https://doi.org/10.1140/epjd/e2004-00183-2

11. D. A. Cremers, and R. C. Chinni, Appl. Spectrosc. Rev., 2009, 44, 457-506. https://doi.org/10.1080/05704920903058755

12. M. Z. Martin, S. D. Wullschleger, C. T. Garten, A. V. Palumbo, and J. G. Smith, J. Dispers. Sci. Technol., 2004, 25, 687-694. https://doi.org/10.1081/DIS-200027329

13. F. C. DeLucia, A. C. Samuels, R. S. Harmon, R. A. Walters, K. L. McNesby, A. LaPointe, R. J. Winkel, and A. W. Miziolek, IEEE Sens. J., 2005, 5, 681-689. https://doi.org/10.1364/AO.42.006148

14. J. S. Becker, J. Su, M. V. Zoriya, J. Dobrowolska, and A. Matush, Eur. J. Mass Spectrom., 2007, 13, 1-6. https://doi.org/10.1255/ejms.833

15. J. P. Singh, and S. N. Thakur (Eds.), Laser-Induced Breakdown Spectroscopy, Second Edition, 2020, Elsevier. https://doi.org/10.1016/C2018-0-03938-9

16. J. Kaiser, O. Samek, L. Reale, M. Liska, R. Malina, A. Ritucci, A. Poma, A. Tucci, F. Flora, A. Lai, L. Mancini, G. Tromba, F. Zanini, A. Faenov, T. Pikuz, and G. Cinque, Microsc. Res. Tech., 2007, 70, 147-153. https://doi.org/10.1002/jemt.20394

17. O. Samek, J. Lambert, R. Hergenroder, M. Liska, J. Kaiser, K. Novotny, and S. Kukhlevsky, Laser Phys. Lett., 2006, 3, 21-25. https://doi.org/10.1002/lapl.200510051

18. M. Galiova, J. Kaiser, K. Novotny, O. Samek, L. Reale, R. Malina, K. Palenikova, M. Liška, V. Cudek, V. Kanicky, V. Otruba, A. Poma, and A. Tucci, Spectrochimic. Acta B, 2007, 62, 1597-1605. https://doi.org/10.1016/j.sab.2007.10.040

19. U. Kramer, and A. N. Chardonnes, Appl. Microbiol. Biotechnol., 2001, 55, 661-672. https://doi.org/10.1007/s002530100631

20. T. Macek, M. Mackova, D. Pavlikova, J. Szakova, M. Truksa, S. Cundy, P. Kotrba, N. Yancey, and W. H. Scouten, Acta Biotechnol., 2002, 22, 101-106. https://doi.org/10.1002/15213846(200205)22:1/2<101::AID-ABIO101>3.0.CO;2-N

21. T. Macek, M. Mackova, and J. Kas, Biotechnol. Adv., 2000, 18, 23-34. https://doi.org/10.1016/S0734-9750(99)00034-8

22. V. Supalkova, J. Petrek, J. Baloun, V. Adam, K. Bartusek, L. Trnkova, M. Beklova, V. Diopan, L. Havel, and R. Kizek, Sensors., 2007, 7, 743-759. https://doi.org/10.3390/s7050743

23. P. Kotrba, T. Macek, and T. Ruml, Chem. Commun., 1999, 64, 1057-1086. https://doi.org/10.1135/cccc19991057
24. K. Francova, T. Macek, K. Demnerova, and M. Mackova, Chem. Listy., 2001, 95, 630-637.

25. D. K. Tripathi, R. Kumar, A. K. Pathak, D. K. Chauhan, and A. K. Rai, Plant. Agric. Res., 2012, 1, 352-361. https://doi.org/10.1007/s40003-012-0042-6

26. P. K. Rai, A. K. Srivastava, B. Sharma, P. Dhar, A. K. Mishra, and G. Watal, Evid. Based Complement Alternat. Med., 2013, 9. https://doi.org/10.1155/2013/406365

27. D. A. Cremers and L. J. Radziemski, Handbook of Laser-Induced Breakdown Spectroscopy, Second Edition, John Wiley \& Sons, 2006, 302. https://doi.org/10.1002/9781118567371

28. J. Peng, F. Liu, F. Zhou, K. Song, C. Zhang, L. Ye, and Y. He, Trends Analyt. Chem., 2016, 85, 260-272. https://doi.org/10.1016/j.trac.2016.08.015

29. C. Pasquini, J. Cortez, L. M. C. Silva, and F. B. Gonzaga, J. Braz. Chem. Soc., 2007, 18, 463-512. http://dx.doi.org/10.1590/S0103-50532007000300001

30. H. Hegazy, E. A. Abdel-Wahab, F. A. Abdel-Rahim, S. H. Allam, and A. M. A. Nossair, Arab J. Nuc. Sci.Appl., 2014, 47, 80-92.

31. X. Y. Liu, and W. J. Zhang, J. Biomed. Sci. Eng., 2008, 1, 147-151.

32. A. Ciucci, M. Corsi, V. Palleschi, S. Rastelli, A. Salvetti, and E. Tognoni, Appl. Spectrosc., 1999, 53, 960-964. https://doi.org/10.1366/0003702991947612

33. E. Tognoni, G. Cristoforetti, S. Legnaioli, and V. Palleschi, Spectrochimica. Acta B, 2010, 65, 1-14. https://doi.org/10.1016/j.sab.2009.11.006

34. C. Zhao, D. Dong, X. Du, and W. Zheng, Sensors, 2016, 16, 1-13. https://doi.org/10.3390/s16101764

35. P. Modlitbova, A. Hlavacek, T. Svestkova, P. Porízka, L. Simoníkova, K. Novotný, and J. Kaiser, Chemosphere, 2019, 225, 723-734. https://doi.org/10.1016/j.chemosphere.2019.03.074

36. Y. Gimenez, B. Busser, F. Trichard, A. Kulesza, J. M. Laurent, V. Zaun, F. Lux, J. M. Benoit, G. Panczer, P. Dugourd, O. Tillement, F. Pelascini, L. Sancey, and V. Motto-Ros, Sci. Rep., 2016, 6, 1-9. https://doi.org/10.1038/srep29936

37. L. Jolivet, M. Leprince, S. Moncayo, L. Sorbier, C.-P. Lienemann, and V. Motto-Ros, Spectrochim. Acta B, 2019, 151, 41-53. https://doi.org/10.1016/j.sab.2018.11.008

38. B. Busser, S. Moncayo, J. L. Coll, L. Sancey, and V. Motto-Ros, Coord. Chem. Rev., 2018, 358, 70-79. https://doi.org/10.1016/j.ccr.2017.12.006

39. Y. Jiang, J. Kang, Y. Wang, Y. Chen, and R. Li, Appl. Spectrosc., 2019, 73, 1284-1291. https://doi.org/10.1177/0003702819857740.

40. H. S. Kwong, R. M. Measures, Anal. Chem., 1979, 51, 428-432. https://doi.org/10.1021/ac50039a025

41. C. Zhu, Z. Tang, Q. Li, R. Zhou, J. Lv, W. Zhang, K. Zhan, X. Li, and X. Zeng, Sci. Total Environ., 2020, 738, 139402. https://doi.org/10.1016/j.scitotenv.2020.139402

42. V. S. Dhanada, S. D. George, V. B. Kartha, S. Chidangil, and V. K. Unnikrishnan, Appl. Spectrosc. Rev., 2020, 30, 1-29. https://doi.org/10.1080/05704928.2020.1800486

43. S. Ma, X. Gao, K. M. Guo, M. Kahsay, J. Q. Lin Sci. China Phys. Mech. Astron., 2011, 54. https://doi.org/10.1007/s11433-011-4493-8

44. G. G. A. Carvalho, J. Moros, D. Santos, F. J. Krug and J. J. Laserna, Anal. Chim. Acta., 2015, 876, 26-38. https://doi.org/10.1016/j.aca.2015.03.018

45. J. N. Kunz, D. V. Voronine, B. A. Ko, H. W. H. Lee, A. Rana, M. V. Bagavathiannan, A. V. Sokolov and M. O. Scully, J. Mod. Opt., 2017, 64, 942-947. 
https://doi.org/10.1080/09500340.2017.1287434

46. P. K. Rai, D. Jaiswal, D. K. Rai, B. Sharma, and G. Watal, J. Food Biochem., 2010, 34, 78-92. https://doi.org/10.1111/j.1745-4514.2009.00265.x

47. J. D. Santos, L. C. Nunes, G. G. A. Carvalho, M. S. Gomes, P. F. Souza, F. O. Leme, L. G. C. Santos, and F. J. Krug, Spectrochimica. Acta B., 2012, 71, 3-13. https://doi.org/10.1016/j.sab.2012.05.005

48. J. Kaiser, M. Galiova, K. Novotny, L. Reale, K. Stejskal, O. Samek, R. Malina, K. Palenikova1, V. Adam, and R. Kizek, Modern Research and Educational Topics in Microscopy, 2007, 1, 434-441.

49. J. Kaiser, M. Galiova, K. Novotny, R. Cervenka, L. Reale, J. Novotny, M. Liska, O. Samek, V. Kanicky, A. Hrdlicka, K. Stejskal, V. Adam, and R. Kizek, Spectroc. Acta Pt. B, 2009, 64, 67-73. https://doi.org/10.1016/j.sab.2008.10.040

50. M. Galiova, J. Kaiser, K. Novotny, J. Novotny, T. Vaculovic, M. Liska, R. Malina, K. Stejskal, V. Adam, and R. Kizek, Appl. Phys. Mater. Sci. Process., 2008, 93, 917-922. https://doi.org/10.1007/s00339-008-4747-0

51. M. Galiova, J. Kaiser, K. Novotny, M. Hartl, R. Kizek, and P. Babula, Microsc. Res. Tech., 2011, 74, 845-852. https://doi.org/10.1002/jemt.20967

52. L. Krajcarova, K. Novotný, M. Kummerová, J. Dubová, V. Gloser, and J. Kaiser, Talanta, 2017, 173, 28-35. https://doi.org/10.1016/j.talanta.2017.05.055

53. M. Z. Martin, N. Labbe, N. Andre, R. Harris, M. Ebinger, S. D. Wullschleger, and A. A. Vass, Spectrochimic. Acta B, 2007, 62, 1426-1432. https://doi.org/10.1016/j.sab.2007.10.046

54. V. K. Singh, D. K. Tripathi, X. Mao, R. E. Russo, and V. Zorba, Appl. Spectrosc., 2019, 73, 387-394. https://doi.org/10.1177/0003702819830394

55. D. K. Tripathi, V. P. Singh, S. M. Prasad, N. K. Dubey, D. K. Chauhan, and A. K. Rai, J. Photochem. Photobiol., 2016, 154, 89-98. https://doi.org/10.1016/j.jphotobiol.2015.11.008

56. M. B. B. Guerra, A. Adame, E. Almeida, G. G. A. Carvalho, M. A. S. Brasil, D. Santos, and F. J. Krug, J. Anal. At. Spectrom., 2015, 30, 1646-1654. https://doi.org/10.1039/C5JA00069F

57. D. K. Tripathi, V. P. Singh, S. M. Prasad, D. K. Chauhan, N. K. Dubey, and A. K. Rai, Ecotoxicol. Environ. Saf., 2015, 113, 133-144. https://doi.org/10.1016/j.ecoenv.2014.09.029

58. D. K. Tripathi, A. K. Pathak, D. K. Chauhan, N. K. Dubey, A. K. Rai, and R. Prasad, Biocatal. Agric. Biotechnol., 2015, 4, 471-479. https://doi.org/10.1016/j.bcab.2015.07.003

59. R. Kumar, D. K. Tripathi, D. Alamelu, D. K. Chauhan, and A. K. Rai, Spectrosc. Lett., 2014, 47, 554-563. https://doi.org/10.1080/00387010.2013.824901

60. F. M. V. Pereira, D. M. B. P. Milori, A. L. Venâncio, M. S. T. Russo, P. K. Martins, and J. FreitasAstúa, Talanta, 2010, 83, 351-356. https://doi.org/10.1016/j.talanta.2010.09.021

61. V. Juve, R. Portelli, M. Boueri, M. Baudelet, and J. Yu, Spectrochimica. Acta B., 2008, 63, 1047-1053. https://doi.org/10.1016/j.sab.2008.08.009

62. P. F. Souza, J. D. Santos, G. G. A. Carvalho, L. C. Nunes, M. S. Gomes, M. B. B. Guerra, and F. J. Krug, Spectrochimica. Acta B., 2013, 83-84, 61-65. https://doi.org/10.1016/j.sab.2013.02.004

63. D. M. Silvestre, F. M. Barbosa, B. T. Aguiar, F. O. Leme, and C. S. Nomura, Anal. Chem. Res., 2015, 5, 28-33. https://doi.org/10.1016/j.ancr.2015.06.003

64. M. Z. Martin, A. J. Stewart, K. D. Gwinn, and J. C. Waller,
Appl. Opt., 2010, 49, C161-C167.

https://doi.org/10.1364/AO.49.00C161

65. L. C. Trevizan, D. Santos, R. E. Samad, N. D. Vieira, L. C. Nunes, I. A. Rufini, and F. J Krug, Spectrochimic. Acta B, 2009, 64, 369-377. https://doi.org/10.1016/j.sab.2009.04.003

66. L. C. Nunes, G. A. Silva, L. C. Trevizan, D. S. Junior, R. J. Poppi, and F. J. Krug, Spectrochimic. Acta B, 2009, 64, 565-572. https://doi.org/10.1016/j.sab.2009.05.002

67. J. Peng, Y. He, Z. Zhao, J. Jiang, F. Zhou, F. Liu, and T. Shen, Environ. Pollut., 2019, 252, 1125-1132. https://doi.org/10.1016/j.envpol.2019.06.027

68. R. Uchida, and J. A. Silva, College of Tropical Agriculture and Human Resources, University of Hawaii at Manoa, 2000, ISBN 1929235-08-8.

69. J. Kaiser, K. Novotny, M. Z. Martin, A. H. Ka, R. Malina, M. Hartl, V. C. Adam, and R. Kizek, Surf. Sci. Rep., 2012, 67, 233-243. https://doi.org/10.1016/j.surfrep.2012.09.001

70. E. Lombi, K. G. Scheckel, and I. M. Kempson, Environ. Exper. Bot., 2011, 72, 3-17. https://doi.org/10.1016/j.envexpbot.2010.04.005

71. L. C. Nunes, J. W. Braga, L. C. Trevizan, P. F. Souza, G. G. A. Carvalho, D. S. Junior, R. J. Poppi, and F. J. Krug, J. Anal. At. Spectrom., 2010, 25, 1453-1460. https://doi.org/10.1039/C003620J

72. M. Yao, J. Lin, M. Liu, and Y. Xu, Appl. Opt., 2012, 51, 1552-1557. https://doi.org/10.1364/AO.51.001552

73. D. F. Andrade, E. R. Pereira-Filho, and P. Konieczynski, J. Braz. Chem. Soc., 2017, 28, 838-847. https://doi.org/10.21577/0103-5053.20160236

74. D. Tewari, H. K. Pandey, A. N. Sah, H. S. Meena, A. Manchanda, and P. Patni, Int. J. Res. Pharm. Biomed. Sci., 2012, 3, 840-845

75. E. Ercioglu, H. M. Velioglu, and I. H. Boyaci, Food Anal. Method, 2018, 11, 1656-1667. https://doi.org/10.1007/s12161-018-1145-x

76. S. Zivkovic, J. Savovic, M. Kuzmanovic, J. Petrovic, and M. Momcilovic, Microchem. J., 2018, 137, 410-417. https://doi.org/10.1016/j.microc.2017.11.020

77. P. Porizka, D. Prochazka, Z. Pilat, L. Krajcarova, J. Kaiser, R. Malina, J. Novotny, P. Zemanek, J. Jezek, M. Sery, S. Bernatova, V. Krzyzanek, K. Dobranska, K. Novotny, M. Trtilek, and O. Samek, Spectrochim. Acta B, 2012, 74-75, 169-176. https://doi.org/10.1016/j.sab.2012.06.014

78. M. R. Martelli, C. Barron, P. Delaporte, G. Viennois, X. Rouau, and A. Sadoudi, J. Cereal Sci., 2009, 49, 354-362. https://doi.org/10.1016/j.jcs.2008.12.007

79. E. R. Schenk, and J. R. Almirall, Appl. Opt., 2010, 49, C153-C160. https://doi.org/10.1364/AO.49.00C153

80. S. Ma, X. Gao, K. Guo, M. Kahsay, and J. Lin, Sci. China Phys. Mech., 2011, 54, 1953-1957. https://doi.org/10.1007/s11433-011-4493-8

81. L. Krajcarova, K. Novotny, P. Babula, I. Provaznik, P. Kucerova, V. Adam, M. Z. Martin, R. Kizek, and J. Kaiser, Int. J. Electrochem. Sc., 2013, 8, 4485-4504

82. J. Han, D. Sun, M. Su, L. Peng, and C. Dong, Anal. Lett., 2012, 45, 1936-1945. https://doi.org/10.1080/00032719.2012.677979

83. S. C. Jantzi, V. Motto-Ros, F. Trichard, Y. Markushin, N. Melikechi, and A. De Giacomo, Spectrochim. Acta B, 2016, 115, 52-63. https://doi.org/10.1016/j.sab.2015.11.002

84. P. Modlitbova, K. Novotný, P. Porízka, J. Klus, H. Zlamalova-Gargosova, and J. Kaiser, Ecotoxicol. Environ. Saf., 2018, 147, 334-341. https://doi.org/10.1016/j.ecoenv.2017.08.053

85. D. A. Navarro, M. A. Bisson, and D. S. Aga, J. Hazard Mater, 
2012, 211, 427-435. https://doi.org/10.1016/j.jhazmat.2011.12.012

86. C. Larue, H. Castillo-Michel, R. J. Stein, B. Fayard, E. Pouyet, J. Villanova, V. Magnin, A. E. P. Del Real, N. Trcera, S. Legros, S. Sorieul, and G. Sarret, Spectrochim. Acta B, 2016, 119, 17-24. https://doi.org/10.1016/j.scitotenv.2012.04.073

87. X. Zhao, C. Zhao, X. Du, and D. Dong, Sci. Rep., 2019, 9, 1-10. https://doi.org/10.1038/s41598-018-37556-w

88. N. Yudasari, S. Prasetyo, and M. M. Suliyanti, Journal of Physics: Conf. Series., 2018, 985, 012011. https://doi.org/10.1088/1742-6596/985/1/012011

89. G. Kim, J. Kwak, J. Choi, and K. Park, J. Agric. Food Chem., 2012, 60, 718-724. https://doi.org/10.1021/jf203518f

90. B. A. Alfarraj, H. K. Sanghapi, C. R. Bhatt, F. Y. Yueh, and J. P. Singh, Appl. Spectrosc., 2018, 72, 89-101. https://doi.org/10.1177/0003702817733264

91. P. Shukla, R. Kumar, A. K. Rai, Appl. Spectrosc., 2016, 83, 872-877. https://doi.org/10.1007/s10812-016-0378-y

92. D. X. Sun, M. G. Su, C. G. Dong, D. C. Zhang, and X. W. Ma, Plasma Sci. Technol., 2010, 12, 478-481. https://doi.org/10.1088/1009-0630/12/4/18

93. W. Q. Lei, V. Motto-Ros, M. Boueri, Q. L. Ma, D. C. Zhang, L. J. Zheng, H. P. Zeng, and J. Yu, Spectrochim. Acta B., 2009, 64, 891-898. https://doi.org/10.1016/j.sab.2009.07.015

94. A. Assion, M. Wollenhaupt, L. Haag, F. Mayorov, C. Sarpe-Tudoran, M. Winter, U. Kutschera, and T. Baumert, Appl. Phys., 2003, B.77, 391-397. https://doi.org/10.1007/s00340-003-1262-z

95. F. Capitelli, F. Colao, M. R. Provenzano, R. Fantoni, G. Brunettia, and N. Senesi, Geoderma., 2002, 106, 45-62. https://doi.org/10.1016/S0016-7061(01)00115-X
96. L. J. Radziemsky, and D. A. Cremers, M. Z. Dekker, New York, 1989, 295-325, Chap. 7.

97. R. S. Harmon, R. E. Russo, and R. R. Hark, Spectrochim. Acta. B, 2013, 87, 11-26. https://doi.org/10.1016/j.sab.2013.05.017

98. V. S. Burakov, S. N. Raikov, N. V. Tarasenko, M. V. Belkov, and V. V. Kiris, J. Appl. Spectrosc., 2010, 77, 595-608. https://doi.org/10.1007/s10812-010-9374-9

99. M. A. Badday, N. Bidin, Z. H. Rizvi, and R. Hosseinian, Chem. Ecol., 2015, 31, 379-387. https://doi.org/10.1080/02757540.2014.961436

100. H. V. M. Nguyen, S. J. Moon, and J. H. Choi, Monit. Assess., 2015, 187, 28. https://doi.org/10.1007/s10661-015-4286-Z

101. R. D. Harris, D. A. Cremers, M. H. Ebinger, and B. K. Bluhm, Appl. Spectrosc., 2004, 58, 770-775. https://doi.org/10.1366/0003702041389201

102. J. E. Haddad, D. Bruyere, A. Ismael, G. Gallou, V. Laperche, K. Michel, L. Canioni, and B. Bousquet, Spectrochim. Acta. B, 2014, 97, 57-64. https://doi.org/10.1016/j.sab.2012.11.007

103. G. S. Senesi, M. D. Aglio, A. D. Giacomo, O. D. Pascale, Z. A. Chami, T. M. Miano, and C. Zaccone, Clean - Soil, Air, Water, 2014, 42, 1-8. https://doi.org/10.1007/s10812-017-0566-4

104. G. S. Senesi, J. Cabral, C. R. Menegatti, B. Marangoni, and G. Nicolodelli, Trends Anal. Chem., 2019, 118, 453-469. https://doi.org/10.1016/j.trac.2019.05.052

105. D. Heuser and D. S. Walker, J. Anal. At. Spectrom., 2004, 19, 929-931. https://doi.org/10.1039/b400801d

106. B. B. S. Jaswal and V. K. Singh, Appl. Spectrosc. Rev., 2015, 50, 473-498. https://doi.org/10.1080/05704928.2015.1010206 